\title{
On Preserving the Natural Environment
}

\author{
Mark Sagoff $\nmid$
}

I. Animadversions on Legal Rights for Natural Things

A

"Much more can be done with plastic trees and the like to give people the feeling that they are experiencing nature." Martin Krieger offers this remarkable bit of advice in his article, "What's Wrong with Plastic Trees?" He continues: "Artificial prairies and wildernesses have been created, and there is no reason to believe that these artificial environments need be unsatisfactory for those who experience them." $1 \mathrm{He}$ is right. In two sentences, Krieger has fashioned something of a reductio ad absurdum of contemporary "utilitarian"2 arguments for preserving the environment.

Think about it. Environmentalists themselves urge us to wear imitation rather than real fur coats. And athletes often prefer astroturf to real grass. Not only they: homeowners are beginning to see the advantages of artificial lawns-"bright, beautiful, durable, and fade resistant," just as the Monsanto Corporation claims. "L. D. Beachene of Oklahoma City . . . got sick of trying to keep his lawn green," reports the Philadelphia Inquirer. The newspaper continues:

So he figured out how much it would cost him in fertilizer, water, insecticides, hoses, sprinklers and what all, and decided it wasn't worth it. He had the whole lawn ripped up and replaced with

+ Assistant Professor of Philosophy, University of Pennsylvania.

1. Krieger, What's Wrong with Plastic Trees?, 179 ScIence 446, 453 (1973).

2. A formulation of classical utilitarianism would be:

$A$ voluntary action is right, whenever and only when no other action possible to the agent under the circumstances would have caused more pleasure; in all other cases it is wrong.

G.E. MOORE, Ethics 13 (1963). See generally J. BenthaM, The TheORY OF Legislation 3 (C.K. Ogden ed. 1950); J.S. Mill, Utilitarianism, LiberTy and Representative GovernMENT 6 (1910):

The creed which accepts as the foundation of morals Utility or the Greatest Happiness Principle, holds that actions are right in proportion as they tend to promote happiness, wrong as they tend to produce the reverse of happiness. By happiness is intended pleasure and the absence of pain, by unhappiness, pain and the absence of pleasure.

In contemporary usage, "happiness" is often taken to mean "benefits" as used in economic analysis, rather than "pleasure." 
artificial turf and phony shrubs at a cost of $\$ 7,000$. His neighbors thought he was crazy. But now Oklahoma City is caught in a drought and every lawn looks like Death Valley-except his. ${ }^{3}$

L. D. Beachene is smart. His neighbors may be snobbish or conservative; but he understands the ancient principle that there is more comfort and amenity in an artificial environment than in a natural one-and at less cost. He could point out that his lawn stays green all year, as do his plastic trees. As for amenity: no mowing, no raking, no weeds! But more important, as he might say, artificial lawns and trees, like imitation fur coats, are good for the ecology. Plastic trees do not need insecticide. And a plastic covering all but eliminates erosion. If we use artificial environments for recreation, moreover, then our national parks and forests can be converted to farmland. This would increase the supply of oxygen, protein and the like-assuming, for the time being, that these are not more efficiently and cheaply produced by machine. Thus it is in our interest to timber Sequoia National Park, plant soybeans there instead, and reproduce the redwoods in lifelike plastic nearer to Disneyland, where more tourists could enjoy them. This is sound ecology: soybeans are better oxygen and protein producers than trees, and they return more to the soil. People might even pay to see manmade trees, properly advertised; there would be fine new land for agriculture; and we would have all that lumber besides! There is no need to labor the point. From the perspective of wealth, power, comfort, amenity-and ecologynothing is wrong with plastic trees.

It is no objection that the wonders of nature, once destroyed, cannot be reproduced. Logically speaking, nothing can come back into being after it has been destroyed. But many things can be replaced. Natural environments are among them. Similarly, it is no objection that the wonders of nature are unique. Logically speaking, anything can be described in a way which distinguishes it from everything else; therefore, everything is unique. But it is the demand for the unique or scarce that makes it valuable. And, as Krieger notes, "the demand for rare environments is a learned one." 4 It seems likely, he says, that "conscious public choice can manipulate this learning so that the environments which people learn to use and want reflect environments that are likely to be available at low cost." "This is the reason that

3. Phil. Inquirer, Aug. 4, 1974, at 3, col. 1.

4. Krieger, supra note 1 , at 451.

5. Id. at 453 . 
the redwoods are replaceable by plastic trees. "The advertising that created rare environments," Krieger writes, "can create plentiful substitutes." ficial forests-as it has for cigarettes, politicians, and toothpastes.

If you are now concerned that you might be advertised into living in and enjoying a plastic world, you will be reassured to know that your government has taken up the cause of nature. In an advertisement currently heard on radio, the Forest Service has issued a succinct, rational, utilitarian argument in favor of real trees. Here it is:

With all due respect to the millions of dog owners, it may well be that a tree is man's best friend. Trees help to supply the oxygen we need to breathe; they keep our air supply fresh by using up carbon dioxide that we exhale and that factories and engines emit. Trees lower air temperatures, and reduce noise pollution by acting as barriers to sound. Trees camouflage our scenery by acting as buffers for unsightly city dumps, auto grave yards and mine sites. They offer a natural challenge for youthful climbers and make excellent perches for Robinson Crusoe style playhouses. . . . Trees break the monotony of endless sidewalks and miles of highway; they beautify our gardens, grace our backyards, and increase the value of property. Trees provide for a share of America's economic growth and stability, and best of all, trees are a renewable resource. ${ }^{7}$

It is fair to conclude that the utilitarian argument for preserving the natural environment, much touted by conservationists earlier this century, ${ }^{8}$ is refuted, damned more by the Forest Service's assertion of it, than even by Krieger's savage reductio. But isn't there one good utilitarian argument left? Aren't real trees and natural environments more beautiful than plastic ones? In the literature of philosophy the "beautiful" is usually defined as a source of disinterested pleasure. Kant, for example, defined beauty this way, following his predecessor Mendelssohn. Mendelssohn wrote: "It appears to be a particular mark of the beautiful that it is contemplated with quiet satisfaction, that it pleases, even though it be not in our possession, and even though we be never so far removed from the desire

6. Id. at 451 .

7. Radio advertisement, U.S. Forest Service, in use by WXPN, Philadelphia, during the summer of 1974.

8. See, e.g., S. HAys, Conservation and the Gospel of Efficiency: The Progressive Conservation Movement 1890-1920 (1959); W. Horbaugh, THE Life and Times of THEODORE ROOSEVELT 306 (1961) (Theodore Roosevelt's first Conservation Message to Congress: "The fundamental idea of forestry is the perpetuation of forests by use"). 
to put it to our use."9 This definition has never changed: "Beauty," said Santayana, "is pleasure perceived as a property of an object." 10 Because the beautiful is valued as a source of pleasure, appeals to beauty are essentially utilitarian, even though or perhaps because the pleasure is in the immediate perception and requires no intermediate use.

As you might expect, Krieger believes that an artificial environment can be as beautiful as a natural one if it adequately resembles it. He makes an analogy to art. "If the forgery provides us with the same kind of experience we might have had with the original, except that we know it is a forgery, then we are snobbish to demand the original." $11 \mathrm{He}$ is undoubtedly right. The point is not that a reproduction and an original cannot be told apart-most certainly they can-but that the difference favors the beauty of a good reproduction over that of the original. Its lines are cleaner and colors clearer. Mark Twain once wrote that he took more pleasure in forgeries than in original Old Masters. ${ }^{12}$ The style or technique of the forgery, he said, is more advanced and familiar; therefore it is easier to assimilate. Art may not gild a lily, but it can fabricate a tree.

If this reply is not convincing, here is another. As long as the expressive qualities of an environment are in question, there are, as we shall see, grounds for agreement, but when it is a matter of beauty, there can be only opinion. To have a single opinion we need a single judge, a censor to protect the amenity of the environment much as we have censors to protect the morality of art. Actually, we have no professional censors of morality, but ordinary juries of ordinary people-who are freely laughed at and ignored by other ordinary people. But censors of environmental beauty would be professionals. They would take courses in forestry and geology and learn all about the way trees camouflage our scenery and act as buf-

9. Quoted in 2 F. Ueberweg, History of Philosophy 528 (1874); cf. I. Kant, Critique OF JUDGMENT 45 ( $\mathrm{J}$. Bernard transl. 1968) ("Taste is the faculty of judging an object or a method of representing it by an entirely disinterested satisfaction or dissatisfaction. The object of such satisfaction is called beautiful').

10. G. Santayana, The Sense of Beauty 51 (1955).

11. Krieger, supra note 1 , at 450 .

12. See H. Tietze, Genuine and False: Copies, Imitations, Forglies 55 (1948): “Art of the past, however venerable it may bc, retains a residuc of strangeness hard to assimilate and even the most fervent worshipper of the past has only by habit and training conquered this natural reluctance which, incidentally, may add to its distinction.... In the untrained onlooker the resistance is absolutely natural and genuine. That is why, as Mark Twain discovered in the great European galleries, the modern copies of old masterpieces were always more pleasant to look at than the masterpieces themselves. This automatic reaction works still more strongly in the case of a forgery which flatters modern taste and at the same time is supposed to be a monument of the past." 
fers for our dumps. It is not difficult to see how systems analysis of beautification benefits or benefits analysis of beautification systems can carry on where Krieger left off. And why should these professionals stop at the environment? Why not take advantage of their expertise to improve the beauty of architecture? And clothing? And art? Why stop at beauty? Enough. We have sufficient trouble fending off developers; we don't need experts as well.

And if you are still unconvinced-here is a third reflection, more important than the other two, which shows that beauty cannot, in general, be given as a reason for preserving an environment. This criticism gets at the fault of many utilitarian arguments. Beauty, as we said, is valued because it is a source of pleasure. But pleasure is merely contemptible. Perhaps you do not recognize immediately that this is true. Here, then, are examples of three pleasures which are clearly contemptible; you will then see that beauty is a fourth. Prostitution must be pleasurable; otherwise no one would pay for it. Flattery is absolutely delightful. And public floggings and hangings have long been a source of enjoyment. If there were an execution in the next street, as Burke observes, ${ }^{13}$ the theater would be empty. You might think it is the humiliation of the prostitute, the guile of the flatterer, or the suffering of the prisoner, which calls up or justifies our disgust; but this is not so: it is the pleasure that is had in them. The prisoner may well deserve his beating. His crimes may be so heinous that he must be hanged; the public ceremony does not worry him. On the contrary, it obviously is to his benefit: a public hanging, as Bernard Shaw has pointed out, ${ }^{14}$ makes a hero of the prisoner, gives him a trip through crowds, lets him see the city and the sunshine, offers him a chance to address the public, and it protects him from his captors, who cannot add, as they do in private, to his punishment. The flatterer may be without guile. And in our society the interest a man has for a woman-the point has been made many times-does not distinguish that she is a prostitute, a doctor, a diplomat, or a housewife. He wants to know only if she is attractive and available. As a result, the prostitute, if a woman, is the only one who is not humiliated: she, at least, is paid, and thus turns the venality of our culture to her own account. Besides, she needs employment-and hers may well be the best society provides. All this is obvious. It merely underscores the fact that we condemn

13. W. Hazcitt, On the Pleasure of Hating, Selected Essays of William HazLitT 245 (1930.)

14. G.B. Shaw, Killing for Sport, Selected Prose of Bernard Shaw 931 (1937). 
prostitution, as we condemn other victimless crimes, not for the pain, but for the pleasure they produce. And rightfully; the pleasure a person takes in prostitution, flattery or in the suffering of others utterly degrades him. It tears away whatever moderation, thoughtfulness, restraint, or self-respect he might have had and reveals the imbecile and the Yahoo. These examples remind us that pleasure does not justify what we do; rather, it is what we do that justifies the pleasure we take in it-or the pain.

Now we have seen that some pleasures are wanton and malignantbut not every pleasure. What of the enjoyment of beauty in nature and art? Surely this is the most oppressive pleasure of all. It is a truism that the rich reap the benefits of programs which improve the quality of the environment while the poor pay the cost. Krieger, for example, has published a paper detailing how "Federal environmental policy is such that the rich get richer and the poor get poorer."15 Rich people, for example, have the background and leisure to cultivate a taste in beautiful environments, and only they have the money to live in or near them. Rising property values in protected areas drive the poor out. If the pleasures of the poor were measured equally with those of the rich, then, quicker than you can say "cost benefit analysis," there would be parking lots, condominiums, and plastic trees. This, in itself, is boring. But it does suggest the fact that philosophers who tell us that a disinterested pleasure need not be an uninterested one may be correct as a matter of logic, but, empirically speaking, they are whistling in the wind. ${ }^{10}$ Viewed disinterestedly, beauty is often trivial. It is our desire to possess it, and to aggrandize ourselves with its exclusive possession, that makes beauty interesting. This can be seen immediately in the case of art. The greatest paintings-think of Picasso's Guernica or Van Gogh's Rooks over a Cornfield or any other-are expressive, passionate, profound; they are not ornamental, not decorative. Some are painful, even torture to look at, if looked at rightly; they are far more ugly than beautiful. Go to a museum full of beautiful paintings, and you soon wonder what you came for-though you might ga to a gallery to choose one for your home.

15. Krieger, Six Propositions on the Poor and Pollution, 1 PoLICY ScIences 311, 318 (1970).

16. Kant wrote, "A judgment upon an object of satisfaction may be quite disinterested but yet very interesting, i.e., not based upon an interest, but bringing an interest with it ..." I. KANT, supra note 9, at 39. 
If the appreciation of beauty in art is appreciation of the cosmetic, the orthodox, the merely agreeable, at least it is innocent. Nobody else suffers if someone is insensible to the important qualities of art. The case is altogether different if you consider, for example, the beauty of human beings. Human beauty, the beauty of women in particular, is considered a great prize, and the man is envied who is seen with a beautiful woman, envied more if he monopolizes her company, and most of all if he can accomplish the supreme indignity of treating her as an ornament to himself. He praises her figure and face but the satisfaction is hardly disinterested; it lies in the aphrodisiac effect on him and in the jealousy she produces in his friends. There is no pleasure at all if she is not "his"--even though she is just as beautiful. He becomes insensible to her other attributes, and if she is wise, honest, proud, or intelligent, he is aware of these qualities not because he values them but because they impede his access to the one he does. His resentment is felt by every man who censures a beautiful woman because she acts with less than a single eye to his convenience-and his criticism is usually expressed in moral terms. It is all for beauty. Can any satisfaction be more destructive than this? And yet it is a pleasure-a more ample one than any had in the difficult and tedious alternative: respect.

Now we are in a position to see the utter brutality in advancing beauty as a reason for preserving an environment. Beauty trivializes nature, as it does women and art, if it can be found there at all, for the wilderness, as even Thoreau discovered while in Maine, is a "vast, Titanic, inhuman Nature" which is "savage and dreary" and makes you feel "more lone than you can imagine."17 Nobody takes a 12-foot sloop across the Atlantic because he expects the pleasures of an ocean liner or climbs a really vicious mountain for a view he can have from a plane. No, he goes because he respects nature and wants to pit himself against and conquer it. If it were for beauty, he could have stayed in his garden or gone to his country club. If you do seek the beauty to be found in a public garden or park, that is harmless, of course, but you find that you do not relish the landscape if you must share it with others. Their presence cloys your satisfaction and you resent them more than you enjoy yourself. Even the sign of someone else's presence-an empty beer can perhaps-offends you unless it is yours; you want to get away from everyone and have an unspoiled place of your own. But if you are fortunate to be able

17. $3 \mathrm{H}$. Thoreat, The Maine Woods, The Writings of Henry David Thoreau 85 (1893). 
to purchase one, you work all kinds of changes to make it liveable. You build a house, you put in lawns and shrubbery and a place to park cars, you refuse to pave, but you build a tennis court. Then you invite your friends-whose presence you do not resent, because they are there at your pleasure, and not you at theirs. If you want a pretty painting or a good-looking companion, at least you do not petition the government to help you and to protect your interest. But as soon as you have your land settled as you like it, you demand a law to keep your neighbor from dividing his five acres. And this, you suppose, is for only disinterested, aesthetic reasons! It is venality reduced to a principle.

Any fool with a house in the country can, on his part, reply that the pleasure one takes in beauty is of a higher or nobler sort than that found, say, in a pizza stand. But he would have to give some meaning to the terms "higher" and "nobler" in the context, and this has never been done. At most he will say that pleasure in beauty is preferable because it has beauty as an object rather than the taste of a good pizza. This would be an unexpected circuit. We are told at first to value beauty because it is a source of pleasure; now we are to value the pleasure, because it has beauty as its source. And so there is as perfect a circle on earth as there is in heaven. The terms "beauty" and "amenity" have, like "law and order," become something of a code. Beauty is no longer just in the eye of the beholder-but in his backyard as well. And "amenity," though deriving from the Latin amoenus meaning "pleasing," now signifies the property of not having to step over too many bodies on the way to the beach. It is all very pleasant: restrictions on land use do produce a gurgle of joy in the bowel of the ruling class-but this is not primarily an aesthetic satisfaction. Through trusts, preservation societies, and zoning, the rich are accomplishing today what in the Middle Ages was achieved by primogeniture and mortmain.

It is reasonable to conclude that except for the fact that our technology cannot yet take over all the functions of nature, we find no utilitarian argument for preserving the natural environment.

\section{B}

In "Ways Not to Think about Plastic Trees: New Foundations for Environmental Law," 18 Professor Laurence Tribe recognizes the

18. Tribe, Ways Not To Think About Plastic Trees: New Foundations for Environmental Law, 83 YALE L.J. 1315 (1974). 
importance and accepts the outcome of Krieger's superb article. "The perpetually green lawn and the plastic tree ..." he writes, "are expressions of a view of nature fully consistent with the basic assumptions of present environmental policy." He continues: "These assumptions ... make all environmental judgment turn on calculations of how well human wants, discounted over time, are satisfied." 10 Tribe is aware that the "intellectual tradition that regards the satisfaction of individual human wants as the only defensible measure of the good . . . is echoed . . . in the environmental legislation which protects nature not for its own sake but in order to preserve its potential value for man." ${ }^{20}$ As long as we operate within that tradition "any claim for the continued existence of threatened wilderness areas or endangered species must rest on the identification of human wants and needs which would be jeopardized by a disputed development." The application of Krieger's analysis follows swiftly. "As our capacity increases to satisfy those wants artificially, the claim becomes tenuous indeed." 21 How, then, to save our natural environment? In his article, Tribe offers "an attempt to identify the roots and expose the inadequacies of this homocentric perspective" and tentatively to "outline the shape of an alternative foundation for environmental law." 22

There are many who would locate the "roots" of this "homocentric perspective" right in the human soul: as a lot, human beings find this perspective most natural. The wonder is that, in a very few thousand years, they have even learned to "discount" their wants over time. Whatever the merits of this analysis, Tribe prefers a different one. He locates the "roots of our current posture"23 "deep within the Western philosophical and theological tradition," 24 particularly in "the radical dichotomy between God and [the] World."25 The point is, of course, that as long as spirit and matter are separated, people will identify themselves with spirit and, perhaps, feel more free to do as they will with matter. This insight is plausible and suggestive-but we have time only to consider what Tribe calls the "inadequacies" of the "homocentric perspective." We have seen that utilitarianism, as it is understood today, may very well lead to an

19. Id. at 1317.

20. Id. at 1325 .

21. Id. at 1326 .

22. Id. at 1317 .

23. Id. at 1392 .

24. Id.

25. Id. at 1333. 
environmental policy some Americans find distasteful; this is a reason to look for a different theory. But although some of us find this consequence of contemporary utilitarian theory objectionable, even unacceptable, this fact does not show of itself that the theory is inadequate. At most it shows that people do not favor its result. There may be problems with utilitarianism which produce this result; but we do not yet know what these problems are. Tribe concedes that fragile values, conflicting goals, and the fluidity of means and ends, usually taken to be bugaboos for a utilitarian modelling, however based, are really only "technical obstacles," and "none of the obstacles need prove insuperable." 26 Where, then, is the inadequacy of our present perspective?

"We can be truly free ..." Tribe writes, "only if we act out of obligation ...." He continues: "To be free is not simply to follow our ever-changing wants wherever they might lead. To be free is to choose what we shall want, what we shall value, and therefore what we shall be."27 Truer words have never been uttered (and no words have been uttered as often), but isn't this consistent with standard utilitarianism? Nobody, surely not the utilitarian, has advocated following seriatim our ever-changing wants. That is a view identified, perhaps, as naive psychological hedonism. It is a straw man. Tribe himself has provided some counsel to the utilitarian in dealing with changing and conflicting purposes-sort of a calculus of utilities brought up to date. Thus the utilitarian imposes an obligation on man-to act after principles which maximize the general pleasure. What is more, if Tribe is right, as he is, about the arrogance of the Western philosophical and theological tradition, we can accept this obligation "without losing the thread of continuity that integrates us over time and imparts a sense of our wholeness in history . ..."28 Accordingly, a utilitarianism based on human wants-the "want-oriented perspective"-is adequate in the sense that it permits us to be free.

But there is a distortion, Tribe asserts, implicit in the homocentric want-oriented perspective. It is this: obligations of other kinds-religious, aesthetic, what not-are perceived, if they are perceived at all, as expressions of merely personal wants: "the felt obligation will be translated into the terminology of human self-interest." 20 This

26. Id. at 1330 .

27. Id. at 1326-27.

28 . Id. at 1327 .

29. Id. at 1330 . 
leads the environmentalist, Tribe says, into the trap of "articulating environmental goals wholly in terms of human needs and preferences." This mistake is fatal because it helps "to legitimate a system of discourse which so structures human thought and feeling as to erode, over the long run, the very sense of obligation which provided the original impetus for protection efforts." 30 Worse still, once felt obligations have been expressed in terms of human interests, there is a strong temptation to give them a dollar denominator. "The translation of all values into homocentric terms thus creates two distortions: First, an inchoate sense of obligation toward natural objects is flattened into an aspect of self-interest; second, value discontinuities tend to be foreshortened." 31

It must now be registered that what Tribe refers to as "a system of attitudes and assumptions which treat human want satisfaction as the only legitimate referent of ... choice" is a well reasoned and articulated moral theory and not an "ideological bias,"32 as he claims. Although Tribe refers to Mill and Bentham, among other "such utilitarian philosophers," 33 and even associates "this metamorphosis of obligation into self interest" 34 with Mill's utilitarian theory, he avoids the term "utilitarianism," preferring sobriquets, e.g., a "homocentric want-oriented perspective." 35 Once we have seen through this pasquinade, we understand that Tribe is talking about a well-known moral position, with roots not only historical and ideological but logical and philosophical, and therefore we conclude that something more is needed to show that "the homocentric logic of self interest leads finally not to human satisfaction but to the loss of humanity." 36 The refusal of a utilitarian to acknowledge obligations other than those of human desires does not reflect his moral blindness but his clear-headedness: he does not distort these other "obligations," he denies them. His ability to "translate" such obligations as he can understand into "smoothly exchangeable units of satisfaction, such as dollars" is not a perversion but a rather stunning accomplishment. Thus, if utilitarianism flattens an inchoate system of obligation into

30. Id. at 1331 .

31. Id. at 1332.

32. Id.

33. Id. at 1327 .

34. Id. at 1331 .

35. Id. at 1329 .

36. Id. at 1348 . 
an aspect of self-interest, that gives this system at least some form of articulation. And if value discontinuities tend to be foreshortened, at least we have a principle on which to make value out. It is perfectly reasonable to say that utilitarianism leads to an environmental policy to which you are not favorable. If only enough people agreed with you, we should have your policy, and on utilitarian grounds. But the fact remains that you are without any kind of an alternative theory-other than an inchoate feeling which a utilitarian identifies as just that-on which to base your own policy. It is only when you understand-by reading utilitarian philosophers-how trenchant, how meticulous, and how lucid their argument is that you can appreciate the hard work needed to establish even the shadow of an alternative moral theory.

Once we have understood that the "homocentric want-oriented perspective" refers to the utilitarian tradition, we see immediately that it is not homocentric in the same way it is want-oriented. This observation by John Hospers, an historian of ethics, bring's out the distinction:

The utilitarian is committed to the maximization of happiness wherever it may exist-in animals as well as in men. Human beings, of course, are the only creatures that are known to enjoy happiness or to be capable of it; whether, and to what extent, dogs or fish or beetles are capable of happiness is a terribly sticky question, and utilitarians could well disagree about that without disagreeing on the principle that happiness is intrinsically good wherever it is found. ${ }^{37}$

Now, Tribe quotes a passage in which Bentham "explicitly extends utilitarian ethics to man's relationship with lower animals." ${ }^{38}$ Was there ever a utilitarian or anyone else who would deny that we should take animal or other wants into account? Of course not; our most scandalous writers do not gainsay so stultifying a platitude. Patriotism, marriage, even motherhood are attacked, but indifference to the suffering of animals is obvious sadism. Even Descartes, who argued that animals are automatons and therefore had no wants, was in every other way a normal man, and therefore would certainly have concerned himself with the feelings of brutes, had he thought they had any. The reason that we do not every day attest our responsibility to

37. J. Hospers, Human Conduct: An Introduction to the Problems of Ethics 236 (1961).

38. Tribe, supra note 18 , at 1328 n.62. 
weigh the happiness of animals against our own is that we do not know how this weighing is to be done-and nobody has thought it worthwhile to assert the principle without accompanying it with at least some explanation as to how it is to be applied. There simply has not been a case of that. Where the obvious interests of animals and those of humans do not conflict, there is no problem, and so there are laws as old as the Judeo-Christian tradition which govern the slaughter house. Discussion-any discussion-begins where these interests conflict. Do we preserve the great flocks of passenger pigeons if they make it impossible for us to plant wheat? What of the recent unpleasantness in Grayson, Maryland, when millions of birds descended on the town? Is their happiness quotient increased by their number? Should the townspeople have moved out? Of course notbut why?

Even Smokey the Bear does not tell us about our obligation to our furry companions without giving us a little analysis about how that obligation is to be carried out: he says something like "Don't be careless with fire." It is fair to conclude that the way to make the want-oriented homocentric perspective less homocentric is not to say that it ought to be, but to show how it can be; this is the task. And, as Hospers says, it's a sticky one. Alternatively, we can give up the basis of wants, desires, pleasure-and thus part with utilitarianism. But when we part with such a friend we get a formidable opponent. And yet how else-except to go beyond not just human wants but the basis of wants altogether-can we make sense of the "inchoate" system of obligations, especially to the environment, that we feel?

Toward the end of his article, Professor Tribe writes that we can feel empathy with plants as well as with animals. "And, once the bases for empathy are thus established, biologists and ecologists can obviously enrich our understanding of what 'needs' exist for other life forms with whom we have begun to feel a new kinship." He continues:

What is crucial to recognize is that the human capacity for empathy and identification is not static; the very process of recognizing rights in those higher vertebrates with whom we can already empathize could well pave the way for still further extensions as we move upward along the spiral of moral evolution. It is not only the human liberation movements-involving first blacks, then women, and now children-that advance in waves of 
increased consciousness. The inner dynamic of every assault on domination is an ever broadening realization of reciprocity and identity. ${ }^{39}$

Jeremy Bentham could not have articulated as well the way in which the process of recognizing rights paves further extensions along the spiral of moral evolution, but he did express much the same thought. "The day may come," he said, "when the rest of the animal creation may acquire those rights which never could have been withholden from them but by the hand of tyranny. The French have discovered that the blackness of the skin is no reason ..." etc. Now, while a few holdouts might find the analogy between women, blacks and children on the one hand and animals on the other, at least as Tribe makes it, less than a perfect one, no one, as we have seen, could disagree with the basic idea: that we empathize with animals and should average their wants in with our own. One gets to that turn in the moral spiral when one is four years old. The point would be to discover a procedure for determining these wants and-far more importantly-deciding how they are to be reckoned against our own. Bringing in the matter of rights or laws does not alter the question; it just asks it in another way. What laws ought to be enacted to protect animals? What rights should they have? How do we settle conflicts between those rights or laws and those that protect us? And so on. Where such questions have been answered, laws have been set up and rights extended, as Tribe says. Commenting on the Federal Laboratory Animal Welfare Act, he writes, "the propriety of legal protection in the interest of the animals themselves becomes more apparent." 10 This propriety could not be more apparent-what is in question is how it is carried out. Exactly what further legislation than we have is feasible? Our ability to answer this question is what is involved in the propriety of asking it. And so to get out of the homocentric perspective we have to find the way of reconciling our differences with animals, not emphasizing our similarities.

How does Professor Tribe help us here? Except for the reference to biologists and ecologists above, the following sums up the contribution.

A passage in Faulkner's Absalom, Absalom! may hold the key: "Maybe happen is never once but like ripples maybe on water after the pebble sinks, the ripples moving on, spreading, the pool attached by a narrow umbilical water-cord to the next pool. ..."

39. Id. at 1345 .

40. Id. at 1344 (emphasis added). 
But there are some shores too remote for even these concentric circles to reach in the foreseeable future. When it is urged that legal protection be extended to non-living entities like canyons and cathedrals, not for our sake but for theirs, it may be precisely such distant shores at which we are asked to gaze. ${ }^{41}$

Now, you ask, what is new about the New Foundations for Environmental Law? Why isn't it the same old homocentric wantoriented perspective?

It's not homocentric is the reply.

\section{C}

Government agencies and commissions face something of a dilemma in connection with the natural environment. On the one side, they work within the assumption that public policy must be hased on public interest. A policy which satisfies no consumer, pleases no faction, benefits no constituency, yet costs a great deal cannot be good. A good policy is one that reconciles a great number of interests; it maximizes the benefits and minimizes the costs. This assumption must be right-else what are cost-benefit analyses, planning commissions, shadow prices, tradeoffs for? On the other side, there is a persistent feeling that natural environments should be protected even if the social and economic benefits of doing so are insignificant in relation to the costs. Moved by this feeling, some people are saying that these environments are to be preserved not primarily for use, not for swimming, or for fishing, or even for looking, but for their own sake. How can this view be reconciled with the assumption, made on all hands, that good policy must serve some interest and confer some benefit in proportion to its cost? The difficulty of this question has led to the creation of interests in nature in terms of which a protectionist policy can be justified-without compromising the assumption that good policies rest on the satisfaction of wants. Hence Tribe's article. And hence the popularity of Should Trees Have Standing? by Christopher Stone, on which parts of Tribe's article are based. ${ }^{42}$

41. Id. at 1345 (footnote omitted).

12. C. Stone, Should Trees Have Standing? (1972). For a contemporary "utilitarian" perspective, see W. Baxter, People or Penguins: The Case for Optimal Pollution (197.1). Occasionally these two perspectives are confused. See, e.g., Sierra Club v. Morton, 405 U.S. 727, 741.42, 74.4-45 (1972) (Douglas, J., dissenting):

Contemporary public concern for protecting nature's ecological equilibrium should lead to the conferral of standing upon environmental objects to ste for their own preservation.... Those who hike [Mineral King Valley], fish it, hunt it. camp in it, irequent it or visit it are legitimate spokesmen for... the inanimate object. 
Professor Stone recognizes that those "who favor development have the stronger argument ... from the point of view of advancing the greatest good for the greatest number of people." 43 He says his suggestion that natural objects be given legal rights and standing "is not just an elaborate legal fiction, but really comes down in the last analysis to a compromise of our interests for theirs." 44 Why should we make this compromise? Stone replies that the question itself is odd:

It asks me to justify my position in the very anthropocentric hedonist terms that I am proposing we modify. One is inclined to respond by a counter: "couldn't you (as a white) raise the same questions about compromising your preferred rights-status with Blacks"; or "couldn't you (as a man) raise the same question about compromising your preferred rights-status with women?"45

Stone reiterates this analogy in respect to Jews as well as blacks and women. Just as white people once thought the unthinkable in respect to conferring rights on blacks, etc., Stone reasons, we might also think the unthinkable thought of representing in court the needs, wants, and interests of animals, rocks, and trees. This is the gist of the argument. As soon as we see that Stone means to modify the "anthropocentric hedonist" 46 perspective only by making it less anthropocentric, and thus that Tribe has followed him accurately in this essential respect, we can conclude that Tribe's proposal is no more interesting than his. At a stroke, Stone and Tribe seem to reconcile the assumption that all policy is to be directed by desires and interests with the felt need to find some rationale for preserving the natural environment. All that has to be done, so it seems, is to countenance the interests of nature along with our own. Secondly, the proposal to give rights to nature immediately indicates the need for, and therefore the employment of, more social and technical planners -professionals who measure the needs or wants of nature and represent them in court. This increases the level of expertise available to society. Third, the "unthinkable" suggestion that trees have rights is really not so unthinkable; Stone quotes Kant and Wittgenstein, among others, to show that suggestions such as his reflect a sound mind. (It is to Stone's everlasting credit that he resorts to Impressive

43. C. Stone, supra note 42 , at 43 .

44. Id. at 44 .

45. Id.

46. Id. 
Quotation-Hegel occurs only once-far less than Tribe.) Finally, the suggestion that trees have standing smothers its authors with glory: it ranks them as emancipators, almost as great as the emancipators of the Jews, blacks, and women. Those who oppose their suggestions, then, may be racists, or anthropocentrists, or whatever they could be called. Woe to them! Together all of nature marches forward in legal equality, with rights for all, without regard to race, creed, color, sex, leaf structure, or atomic number. And all-perhaps even the poor people of Manhattan-will have their day in court!

What is wrong with this suggestion? We have already seen that it is a little vague as it stands. But suppose it were put into effect. Even then we would have no rationale for preserving the natural environment. When only human interests are considered, as Stone admits, there is no "utilitarian" argument against development. Krieger's point is too persuasive: through the magic of advertising, we can learn to enjoy plastic forests and artificial parks. Man has chosen to live in manufactured habitats ever since he came down from the trees; there is no reason to think his trend away from nature will change today. But what about the interests of animals and other natural things? There is every reason to suppose that these interests differ very little from those of man. This conclusion follows from the example with which Stone himself defends the thesis that "natural objects can communicate their wants (needs) to us, and in ways that are not terribly ambiguous." Stone explains: "The lawn tells me that it wants water by a certain dryness of the blades and soil-immediately obvious to the touch-the appearance of bald spots, yellowing, and a lack of springiness after being walked on." 4 t Notice that nature is unlikely to take care of Stone's lawn. He has to water it with a hose, and this is a step toward an artificial, not a natural environment. Now consider how trees choke one another and gasp for air, water, and light. How much happier they would be planted in neat rows, as the timber companies would have them, and saved from their struggle for lifel Consider animals. Many animals already inhabit our houses; no one can maintain that pets, rodents, and vermin would do as well in the wild. And wild animals often show their preference for the sanctuary of a domestic environment. The fawn would take its dinner in a kennel rather than its chances in a wilderness, and thus be sure of eating, rather than being eaten. Geese find the shore of the Schuylkill, where they are fed by the park police,

47. Id. at 24. 
so attractive that they forget their long flight south. The salmon might prefer the aquarium or the fish tank, where it can lay its eggs quietly, without making the arduous journey upstream. There is no reason to think that the interests of animals must differ from ours. Nature is a war of each against all, as Hobbes said, and man and beast alike prefer the safety and comfort of an artificial environment.

The interests of nonliving things are a little harder but perhaps not impossible to imagine. Let us suppose, for the sake of argument, that resorts, factories, and electric plants are not among the objects which have to be represented in court. That leaves us with rivers, mountains, lakes and other natural things. Environmentalists always assume that the interests of these objects are opposed to development. How do they know this? Why wouldn't Mineral King want to host a ski resort, after doing nothing for a billion years? In another few millennia it will be back to original condition just the same. The Sequoia National Forest tells the developer that it wants a ski lift by a certain declivity of its hills and snowiness during the winterimmediately obvious to the sight-and that it needs a four lane highway by the appearance of certain valley passages and obvious scenic turnouts on the mountainsides. The seashore, meanwhile, indicates its willingness to entertain poor people from Oakland by becoming covered with great quantities of sand. Finally, it is reasonable to think that Old Man River might do something for a change, like make electricity, and not just keep on rolling along. It is an incredible optimism which assumes the guardians appointed to represent nature would take an environmentalist position. These guardians would be chosen by the government, in other words by the lobbies, and thus nature could enter suits on the side of development. Man is a part of nature, as Tribe and Stone never weary of telling us; therefore his interests and those of his environment ultimately are the same. A Ho Jo's in the Rockies, then, would benefit nature since it benefits man. If such improvements do not benefit nature, however, it can only be because human interests and those of nature conflict. If so, can we rule out a priori the possibility that since man is the most dangerous animal, a rigorous cost-benefit analysis equitable to all nature would send him back to the caves? This is a real possibility-if objects of nature are always the victims, and never beneficiaries of development.

It would be unfair to Tribe and Stone not to mention the theoretical importance of their argument, particularly as it relates to the 
policy sciences. Let us assume that a policy is justified if its benefits exceed its costs. Tribe and Stone understand that programs which develop natural environments, the Disney proposal to build a ski resort in Mineral King, for example, are generally justified for human populations, but they have pointed out a larger population, also affected, for which these programs are not justified. It is no matter that they seem to have the wrong animals in mind: the interests of the deer, for example, may be served by the management of the resort, but what of the poor vultures who will have nothing to eat if the deer are kept alive all winter on the resort garbage? By judicious choice, in any case, they could have found mountains, planets, gases, even empty spaces, which are affected by the policy and which, when added to the original population, tip the balance of interest in the other direction. Now, a principle is suggested by-or is implicit in -this strategy of argument. It is this: if a policy is justified for a given population, then there is a larger population which is also affected by the policy and which includes the original population; for this larger population, the policy is not justified. Whatever other merits this principle may or may not possess, it has one advantage. It allows us to justify any policy we want.

If we fully understand the progress we are making up the spiral of moral evolution, moreover, we may agree with Tribe that there is no shore so distant that it does not invite our gaze. Thus we arrive at a second principle, which clearly distinguishes the utilitarianism of Tribe and Stone from mere egoism, sexism, racism, anthropocentrism. It is this: the interests of all entities affected by a policy must be taken into account. This principle, which gives ethical force to Tribe's decision to go beyond human wants and to Stone's willingness to count their interests against ours, is not an innovation; the principle, as we have seen, is an old saw of classical utilitarianism. Together with the principle of the larger population, however, it becomes a powerful tool of analysis. It permits us not only to justify any policy we want, but also, in doing so, to adopt a lofty moral tone.

There remains the problem of understanding and measuring the interests of animals and other natural things and there is the difficulty of balancing these interests against our own. ${ }^{48}$ We have to be sure of getting the input right. How do we balance the desire of a

48. Stone and Tribe see the problem as one of "understanding... mankind's place in the universe." See C. STONE, supra note 42, at 28; Tribe, supra note 18, at 1327. But, as Woody Allen has said, "it's hard enough finding your way around Chinatown." W. ALLEN, My Philosophy, in GETTING EvEN 28 (1972). 
pine to live against our interest in the beauty of a plastic tree? Does procedural fairness go at five points and respect for animals at seven? At what figure do we weigh the needs of future generations of various kinds? The difficulty of these questions need not overwhelm us. Tribe, at least, assures us that the techniques of cost-benefit analysis, which distort and flatten our responsibilities when employed in a homocentric perspective, are quite adequate in a more universal context. The concerns which we have mentioned, Tribe says, "can in theory be incorporated in a rigorous analysis, either by using various market price or other numerical surrogates to value extramarket costs or benefits, or by the technique of 'shadow pricing' . . ." 40 There is nothing in the techniques themselves which "precludes their intelligent use by a public decisionmaker in the service of these "intangible,' or otherwise 'fuzzy,' concerns." "50 Now, if these techniques can adequately model our ideals, values, and responsibilities, why do they lead, as Tribe at one point asserts they do, ${ }^{51}$ to the destruction of the natural environment? Do the distortions in our thinking arise only from the fact that our techniques of modelling are used in a homocentric rather than a more universal perspective? Or are they implicit in these techniques themselves? Do we really need the interests of animals, then, to save us and our environment from our own? Have we no other way to make out the nature of our responsibilities? The techniques which have been worked out for economic modelling can help us to implement a policy, once we have settled on one; this raises the question of what our policy shall be. When we have answered this question, we shall know which or whose interests we want to serve, which interests, in other words, are legitimate. And then we shall want no other rationale for counting these interests against our own.

It must be obvious now that the "hedonistic anthropocentric" alias "homocentric want-oriented" perspective leads to an anti-environmentalist position not because it is anthropocentric but because it is hedonistic, and it distorts our felt obligations to nature not because it is homocentric but because it is want-oriented. Make no mistake: the policy which turns our remaining wilderness areas into amusement parks, highlights the scenery with son et lumière, and fêtes the animals with garbage increases the general satisfaction of man, beast, and mountain. If by a "rational" policy, we mean one that

49. See Tribe, supra note 18 , at 1319 .

50. Id.

51. Id. at 1329-30. 
results from the application of our best policy-analytic techniques, then this policy is plainly a rational choice. This fact raises the question whether decision-theoretic procedures for modelling values, no matter how internally consistent, are the only feasible determinants of rational policy; it asks, in other words, whether the context of wants and interests is the only reasonable one. The question can be put in rather brutal terms. As long as policies are intended to maximize the general satisfaction, they will be no better, morally or spiritually, than the interests they serve. If these interests are not already corrupt, perhaps advertising should be used to corrupt them; generally, the more venal a desire the less it costs. But there is no need to bring up issues wider than those which concern the environment. No current environmental policy is both protectionist and consistent with a "hedonistic want-oriented" perspective. Our technology is still somewhat inadequate; nature, therefore, is not yet wholly obsolete. Except for the limit of our technology, however, there is no economic or even utilitarian rationale available for preserving the natural environment. 


\section{America's Covenant with Nature Recognized}

Of the hundred or so persons who landed with the Mayflower, November 11, 1620, at Plymouth, William Bradford tells us that over half died in the first two or three months "especially in January and February, being the depth of winter and wanting houses and other comforts." ${ }^{2}$ The environment, as Michael Wigglesworth described it in 1662, was a "Devil's den,"
A waste and howling wilderness
Where none inhabited
But hellish fiends and brutish men
That devils worshipped. ${ }^{33}$

Bradford and the Pilgrims, Wigglesworth and those who migrated to New England during the latter part of the 17th century, the fur traders after them, the Indian killers, the homesteaders, the empire builders all learned what we would learn if we visited, even for a short while, an uncivilized place: that nature-and nature meant the wilderness for these people-is

marvelous, fantastic, beautiful; but it is also terrifying, it is also profoundly sinister. There is something in what, for lack of a better word, we must call the character of great forests ... which is foreign, appalling, fundamentally and utterly inimical to intruding man. ${ }^{54}$

This is the attitude of the explorer, but when he becomes a settler and has a farm and home, he loses the sense of awe. As Marx once wrote, "Nature becomes . . . purely an object for men, something merely useful, and is no longer recognized as a power working for itself." ${ }^{55}$ In America this change of attitude came very early and very abruptly. For three or four years the Pilgrims recognized nature as a power working for itself; then they made it work for them by clearing it of trees and fertilizing it with dead fish. Every Thanksgiving we celebrate their success. We celebrate the fact that in America, nature is the reverse of hostile, inimical, or foreign; all you have to do is replace the forests with farms and cities, and it nicely serves

52. Quoted in P. Miller \& T. Johnson, The Purrtans 103 (rev. ed. 1963) [hereinafter cited as MILLER \& JoHnSON].

53. Quoted in I2 Proceedings MASs. Hist. Soc'y 83 (1871-1873).

54. Huxley, Wordsworth in the Tropics, 18 YALE REV. 672, 673 (1929).

55. K. MARX, GRUNDRISSE DER KRITIK DER POLITISCHEN OKONOMIE, quoted in W. LEISs, The Domination of Nature 73 (1972). 
the purposes of man. The Puritans in America understood this perfectly; they looked on the wilderness with dread and thanked God every time it was destroyed. They also understood that when forests go down, profits go up, and they thanked God for that as well. "I think it fair to say," writes the historian Perry Miller, "that the founders had no qualms about doing harm to nature by thrusting civilization upon it." He continues: "They reasoned in terms of wealth, comfort, amenities, power, in terms which we may conveniently call, though they had not been derived from Bentham, 'utilitarian." "Eo In the first century or century and a half, Americans did think this way. From the moment when Bradford stepped from the Mayflower into a "hideous and desolate wilderness," the attitude of the American toward nature was, to quote the historian Roderick Nash, "hostile and his dominant criteria utilitarian. The conquest of the wilderness was his major concern." 57

Over the next 200 years, this attitude underwent a remarkable, even incredible, change. At first, Americans thought of the civilized nations of the world, notably England, as the regions blessed by God, while they considered their own environment a howling waste. In 1702, for example, Cotton Mather, while eulogizing a woman, said she had left an "earthly paradise" in England to "encounter the sorrows of a wilderness" in America. Eventually, she "left that wilderness for the heavenly paradise." A hundred years later, Americans came to see the wilderness as the equivalent of Eden, a paradise "fresh as it were, from the hands of the Creator." 58 The city, whether in Europe or America, has become the Devil's den. There is a plausible belief that knowledge of this history is relevant to our environmental policy. A causal connection surely exists between our attitude toward nature and our desire to alter it or keep it as it is. But there is also a logical connection between our aesthetic description of nature-whether we say the wilderness is heaven or hell-and the conclusion we draw about changing or preserving it.

How, then, is this connection to be understood? The aesthetic qualities of natural objects, for example, the strength of a river or the inviolability of the moon, are to some extent cultural creations, just as the entrance of the Pope into St. Peter's is a cultural creation. Those who share in the culture learn to perceive the mightiness of

56. P. Miller, ERrand into the Wilderness 207 (1970) [hereinafter cited as ERrand].

57. R. NASH, WILDERness and THe AMERICAN Mind 23-24 (1967).

58. I C. Mather, Magnalia Christr Americana 77 (1855), quoted in R. Nash, supra note 57 , at 26 . 
the river, just as Catholics may learn to perceive the holiness of the Pope. These objects, indeed, function within a culture as paradigms of the qualities they express. Accordingly, although the determination of the expressive properties of an object depends largely on cultural convention, and therefore on a knowledge of cultural history, the perception is immediate and personal; our feelings function as cognitively as our organs of sense. The fact that the wilderness and the objects in it, given our cultural history, are the paradigms of the qualities we most cherish-freedom, innocence, courage, strength-is not itself a sufficient condition for a protectionist policy; very often we are forced to sacrifice the things we most admire. Nor is it a necessary condition. As long as technology is unable to absorb totally the function of the ecosystem, there will always be a utilitarian rationale for keeping some of nature alive. But it is an important consideration, nevertheless.

What we do with the symbols (the paradigms as we have said) in which we find exemplified certain qualities is a logical condition of how well we respect, or how much we despise, those qualities themselves. The thought here is a very simple one. Suppose there are some qualities you admire-qualities you associate, say, with someone you love, or the town in which you were born, it doesn't matterand you have something that you think really expresses those qualities-let us say, letters from someone you love. You might show the letters to a friend as examples of the qualities you cherish: imaginativeness, thoughtfulness, kindness, and so on. If you treat those letters, or whatever it is, frivolously, discarding them deliberately but without a second thought, then that act would itself be evidence that either you no longer respect those qualities or you no longer think that the letters, or whatever, express them. So it is with our environment. A society which values freedom and which makes its forests or the wildlife in them the expressive symbols of freedom will not treat the forests or the wildlife frivolously, nor discard them without a second thought. If it does, then this act will count as evidence that the society either no longer values freedom or that its paradigms of freedom have changed. They may have changed, for example, from wildlife to motor cars and washing machines. In this case, we can draw the conclusion that the meaning of freedom in that society has itself changed. Accordingly, one way to keep our concept of freedom intact is to respect the objects that express it. Although this thought is a simple one, working it out is tedious and difficult. The first step is to determine what qualities are in fact expressed by the ob- 
jects in our natural environment. We need to have before us enough sense of the historical context to see that it is a fact that our rivers, forests, and wildlife do serve our society as paradigms of concepts we cherish-or at least to see how such a "fact" is established. Accordingly, we need to take a brief look at the historical background to be sure that we can make even this first step toward a nonutilitarian defense of our natural environment.

Except for Thanksgiving and the bathetic experience of John Alden, the Pilgrims gave us little to remember. Unlike the Puritans who came with the Great Migration of 1630, to run "an errand into the wilderness," 50 the followers of Bradford left England to escape persecution, not to make history. And so it is with the landing in Salem, June 12, 1630, of John Winthrop and his group of immigrants, or perhaps with his speech "A Modell of Christian Charity" aboard the Arbella, that our consciousness as a nation begins. In his lay sermon, Winthrop told his people that they came to America not to get a better station in life but to form a better. community "both civill and ecclesiasticall"; that God had appointed them to do so and "wee are entered into a covenant with him for this work"; and that, according to the Covenant, if "wee shall ... embrace this present world and prosecute our carnall intencions seekeing greate things for our selves and our posterity, the Lord will surely breake out in wrathe against us ... and make us knowe the price of the breache of such a covenant." If on the contrary they did the work, and so built a just commonwealth, God would fully reward them: "he shall make us a prayse and glory, that men shall say of succeeding plantacions: the lord make it like that of New England: for wee must consider that wee shall be as a Citty upon a Hill, the eyes of all people are upon us ...."60 Needless to say, Winthrop was entirely mistaken. His people failed to do what he thought was the work of God in America-and yet they achieved an enormous prosperity. They had not intended to become prosperous, and yet they were; prosperity, as John Higginson told the Massachusetts General Court in 1663, had become a remarkable fact of life. In his inaugural sermon, he said:

59. This familiar description is the title of an election sermon preached by the Reverend Samuel Danforth in 1670. S. DANForth, A BRIEF ReCognition of New England's ERRAND INTO THE WILDERNESS (1670).

60. MILler \& Johnson, supra note 52, at 198-99. 
When the Lord stirred up the spirits of so many of his people to come over into the wilderness, it was not for worldly wealth or better livelihood for the outward man. The generality of the people that came over professed the contrary. Nor had they any rational grounds to expect such things in a wilderness. Thou God, hath blessed His poor people and they have increased from small beginnings to great estates. . . . Look upon your towns and fields, look upon your habitations shops and ships and blessings of land and see. Have I been a wilderness to you? We must need answer, no Lord thou has been a gracious God, and exceeding good even in these earthly blessings. We live in a more comfortable and plentiful manner than ever we did expect. ${ }^{61}$

At first, Puritans accepted Winthrop's suggestion that their prosperity came as a reward for their labors. By 1660 , however, they followed Higginson in citing God's free benevolence. Finally, in the 1670's the continued "sweetening" of life in New England could only be regarded as evidence that God did not know what was going on there. Even Higginson included a warning in his sermon. In words much quoted thereafter, he reminded the court that they were "originally a plantation of Religion, not a plantation of trades. Let merchants and such as are increasing cent per cent remember this." ${ }^{02}$ The warnings increased in severity; sermons took on the form of jeremiads, which they were called; and every shipwreck, flood, or drought was recognized as an omen that at last God's vengeance was on its way. When King Philip's War (1675) failed, for all its horror, to make God's will known among His people, the ministers formed a Synod and published as its Result, in methodical fashion, the crimes which they had declaimed for years in their jeremiads. Although some of the sins mentioned there are solid even by today's standard, there was a clear emphasis on the connection between the first, "[a] cooling of former life heate in spiritual communion," and the tenth, an "inordinate affection to the world." ${ }^{3}$ Looking back at these events, we can surmise that the land speculation, dissension, inflation, the lessening of religious ardor, and the other complaints listed by the Synod were not sins but necessities. They represent the attempt of a second and third generation to deal with the social problems their fathers, immersed in the political and theological disputes which brought

61. J. Higginson, The Cause of God and His People in New England 10-11 (1663).

62. Id.

63. This was the Synod of 1679-1680. See P. Miller, Nature's Nation 25, 29 (1967); W. Walker, The Creeds and Platforms of Congregationalism $409-40$ (1893); cf. P. Miller, The New England Mind: From Colony to Province 35 (1967). 
them from England, had not confronted nor even expected. And the jeremiads, the halfway covenants, the revivals, and the like did not so much restrain as exorcise these activities. By offering a ritual mea culpa, the young people could get on with the business of life. But still beneath this was the fact-unacknowledged at the time but always sharply felt-that New England had lost her audience. Cromwell and the Independents, in whose cause the Puritans had come to America, grew more concerned about improving their army than their theology, and when they noticed the Americans at all, it was only to tell them that their zeal was an embarrassment, since they themselves had determined upon a course of toleration. Consequently, the settlers of New England were left with a sense of having a mission-but no idea what it was or for whom; a Covenant-but no assurance of God's interest or understanding of its terms; and a national identity-but no idea what that was or who they were. As Perry Miller put it: "Having failed to rivet the eyes of the world upon their city on the hill, they were left alone with America." 64

America was the wilderness, but what is that? How would a Puritan people describe it? As their history suggests, they were not utilitarians in a philosophical sense; on the contrary, their protestant background would have made them resist a pleasure-pain philosophy. Accordingly, while they did reason about their environment in terms of wealth, power, comfort, and amenity, they valued these advantages not as ends in themselves but as means or as rewards for religious accomplishments, and if they taught themselves to pursue happiness, it was happiness within a new social order and not individual success for its own sake. But when their religious errand failed and no new social order materialized, although there was an abundance of individual success, Americans began to question whether they any longer had a mission of such importance that it merited tearing down a wilderness. They began to ask whether they were corrupting their environment-but only after they discovered, as we have seen, that their environment had corrupted them. The wilderness that had served them had also seduced them, and in destroying it, they destroyed something of their hopes, something of their history, and something of the future as well as of the past. They saw that their prosperity was also an apostasy, their nationalism was also a secularism, and their happiness was also an emptiness. And while they reasoned in terms of wealth, power, comfort, and amenity, they had

64. ERRAND, supra note 56 , at 15 . 
nothing left to serve but themselves. If, after this time, Americans have remained utilitarians, they have been utilitarians faute de mieux. It is a part of our national character to want a devotion to noble purposes, a respect for great symbols, a commitment to important ideals. Of course, we had only one place to look. If we found nonutilitarian paradigms of freedom, intelligence, virtue, courage, and strength, we did so because a puritan people ascribed these qualities to nature itself.

In imposing civilization on so vast a landscape, Americans were, in fact, doing what had never been done. They had a mission-if not the one that brought them-and the world watched. And they had become conscious of new symbols, stories, and beliefs and so had begun to unite themselves, without relying on the traditions, memories, and myths of their European origins. In a word, Americans started to describe nature in a way that could help them describe themselves. It is hardly surprising that this search-the attempt to locate in nature the symbols of national character and destiny-was first conducted in religious terms. In 1755, Jonathan Edwards, then a missionary to Indians at the frontier town of Stockbridge (Northampton had expelled him in 1750 , correctly surmising that it was not good for business to worry as much as he did about the wrath to come), published a Dissertation Concerning the End for which God Created the World, in which he set forward some of his reasons for opposing the rationalist theology of Boston. Although Edwards did not say that God is an Artist rather than a Clockmaker, he has been interpreted as if he did, and properly so, for this clearly is part of his intention. Here is what he said:

Thus it appears reasonable to suppose, that . . . the disposition to communicate himself, or diffuse his own FULNESS, which we must conceive of as being originally in God as a perfection of his nature, was what moved him to create the world. But here, as much as possible to avoid confusion, I observe, that there is some impropriety in saying that a disposition in God to communicate himself to the creature, moved him to create the world. For though the diffusive disposition in the nature of God, that moved him to create the world, doubtless inclines him to communicate himself to the creature, when the creature exists; yet this cannot be all. ... Therefore, to speak more strictly according 
to truth, we may suppose, that a disposition in God, as an original property of his nature, to an emanation of his own infinite fulness, was what excited him to create the world ... . ${ }^{65}$

This is not entirely new. Puritans had long considered nature to be not only a creation but an expression of the power of God. A century earlier, John Cotton, for example, had described nature as "a mappe and shaddow of the spiritual estate of the soules of men."66 And Edwards himself had encountered in nature the "images or shadows of divine things." 67 The Dissertation is unusual, however, even startling, first, because it refuses to go along with Cotton Mather and others in finding the, glory of God expressed primarily in the mechanical perfection of the Newtonian universe, and, second, because it does not hesitate to use such terms as "diffuse," "emanate," and "communicate" to describe God's relation to the world. This is a real departure. Instead of studying science or theology, indeed, instead of staying within the Covenant or any of the conventions of Calvinism, Americans could find in the experience of nature the condition of spiritual awakening. The revivals were founded on this belief. Nature is a symbol of the divine; therefore, the wilderness assures Americans of their special relation to God.

But how is this symbol to be understood? Edwards himself tried to blunt the impact of his words-God does not communicate himself chiefly for the benefit of man-and therefore the symbol is in a foreign character, a faint clue and indirection, a shadow on the wall of a cave. But take away the Calvinist theology, remove the doctrine of original sin, of which Edwards, of course, was a major exponent, and the conclusion would follow from the passage quoted that God, nature, and man, being of one substance, are equally divine. ${ }^{68}$ In that case, like may respond to like, and we may all become

65. 2 J. Edwards, The Works of President Edwards 217-18 (1879).

66. Cotton distinguishes between the study of nature for the sake of scientific and practical knowledge and the study of nature as a symbol of God. These are compatiblc, Cotton says, but those interested only in scientific or practical study are "very quick sighted in points of nature but very dull and heavy in matters of Religion and grace." The scientific study of nature is permissible if it does not lose sight of the symbolic; there is a "settled order" in the changes of the weather "as in the motions of the Heavens"; and we ought to understand it if we can. J. Cotron, A BrIEF Exposimon witir PRACTICALL ObSERVATIONS UPON THE WhOLE BOOK OF ECclesiastes 64-65 (1654), quoted in p. Miller, The New England Mind: The Seventeenth Century 212 (1954). Miller writes: "Young Elnathan Chauncy copied into his notebooks from Samuel Purchase the truism, 'There is no creature but may teach a good soule one step toward his creator,' while Cotton... blessed the study of nature when nature was viewed as "a mappe and shaddow of the spirituall state of the soules of men." "Id. at 213.

67. J. Edwards, Imaces or Shadows of Divine Thincs (P. Miller ed. 1948).

68. ERrand, supra note 56, at 185 . 
transcendentalists, immediately interpreting the messages of God. If you think Emerson drew this inane conclusion, you are obviously right; the theme that flows through him is Jonathan Edwards' old Puritan conviction shorn of its theological restraint:

There is no great and no small

To the Soul that maketh all:

And where it cometh all things are;

And it cometh everywhere. ${ }^{69}$

The easy, all too easy, manner in which the "unfallen" Emerson went about reading the character of God in Nature offended at least some of his contemporaries: Walden, for example, is two miles away and 12 feet deep, and Moby Dick is farther and deeper than that. But whether with the majority of Americans you read Emerson and the great slush of Romantics, and thus saw Nature as the paradigm of joyful innocence and God as essentially benevolent, or you chose Melville, Hawthorne, Poe, or later, Twain, and were made aware of the ancient distances in the deep seas and dark forests, you recognized nature as an aesthetic symbol before you considered it as a utilitarian environment. In order to understand nature as an aesthetic symbol, you had to decide upon its metaphorical character: is it virtuous, independent, mighty, and free, or is it inimical, wrathful, and ambiguous? Now, these qualities belong to nature, if they belong at all, no less than properties of age or chromosome count: metaphorical possession is possession nonetheless. ${ }^{70}$ It is just that the conventions for establishing age or chromosome count are well entrenched in the history of scientific theory, while the conventions for determining metaphorical qualities are necessarily less well entrenched. An example may help. Suppose you wish to know which mountains in the United States are majestic. Why, purple ones, of course! The point is that songs, poems, paintings, plays and the like give us ways to converse with one another about what things are noble or majestic, great or small. If a leaf of grass is no less than the journey work of the stars, then it has a quality not reproducible by the Monsanto Corporation. The commonsense properties of an object are settled by ordinary perception-indeed, this is what makes them commonsensical; the metaphorical qualities, or, if you prefer, the aesthetic or expres-

69. Significantly, this is the motto of his essay, History. R. EMERson, History, in ESSAYs \& EsSays SEcond SERIEs 1 (1969).

70. See N. Goodman, Languages of ART 68 (1968) ("metaphorical possession is not literal possession; but possession is actual whether literal or metaphorical"). 
sive qualities of things are determined by the arts. No wonder the first conservationists-Audubon, Catlin, Cole, Muir, Olmsted-were not pioneers, businessmen, or politicians; they were artists. Only by recognizing the metaphorical or expressive features of nature can one understand the moral dimension of the fact that this country has torn the wilderness down.

The opinion in New England and New York, as represented, let us say, by Emerson and Thoreau in the one and Melville and Whitman in the other, that nature had sublime qualities which could be read or at least translated into our national character received support-it was entirely paralleled, in fact-in the writing of Jefferson and the thinking of the first settlers of Virginia and the South. Although those who lived south of New York tended to visualize America as a garden rather than as a wilderness, and thus their imagery reflects a lower latitude, their emulation of nature was much the same. "What then is the American, this new man?" wrote Crevecoeur, a Pennsylvanian who corresponded with Jefferson and, through his popular Letters from an American Farmer, with the world. "He is an American," Crevecoeur continued, "who, leaving behind him all his ancient prejudices and manners, receives new ones from the new mode of life he has embraced ...." "71 That "new mode of life" was, of course, to be bucolic-the rural life of independent freeholders. Jefferson's distrust of the cities-which he regarded as belonging spiritually to Europe, wherever they were-is well known, as is his reliance on virtues nourished by the land. In Notes on Virginia, Jefferson wrote: "Those who labour in the earth are the chosen people of God, if ever he had a chosen people, whose breasts he has made his peculiar deposit for substantial and genuine virtue." He went on: "Corruption of morals in the mass of cultivators is a phaenomenon of which no age nor nation has furnished an example." 72 Of this sentiment, one historian, Leo Marx, has written: "By 1785, when Jefferson issued Notes on Virginia, the pastoral ideal had been 'removed' from the literary mode to which it traditionally had belonged and applied to reality."73 The pastoral ideal presented as a priori a scheme as the covenant theology of Winthrop, and one that fit reality as badly-apparently, cultivators are no less susceptible of corruption

71. J. Crevecoeur, Letters from an American fakmier 54 (1904).

72. T. JefFerson, Notes ON THE STATE OF Virginia 164-65 (1954).

73. L. Marx, The Machine in the Garden 73 (1964). 
than the same number of merchants. Worse than that, they could not remain cultivators: once the tide of civilization, as it is always called, moved west, those who moved with it had to become woodsmen, hunters, traders, soldiers, or whatever was needed to turn an inhospitable environment into a more comfortable, if more ordinary, place to live. The images of Arcady were no use to them; the banalities of Emerson reflect a man on the Chautauqua Circuit, not the Oregon Trail. Those who moved west in their successive waves-to keep within Frederick Jackson Turner's metaphor-felt the old American antipathy toward the wilderness, and anyway they were concentrating on something else. De Tocqueville says of them:

In Europe people talk a great deal of the wilds of America, but the Americans themselves never think about them; they are insensible to the wonders of inanimate nature and they may be said not to perceive the mighty forests that surround them till they fall beneath the hatchet. Their eyes are fixed upon another sight: the American people views its own march across these wilds, draining swamps, turning the course of rivers, peopling solitudes, and subduing nature. This magnificent image of themselves does not meet the gaze of Americans at intervals only; it may be said to haunt every one of them in his least as well as in most important actions and to be always flitting before his mind.74

In 1840, the New York Review, in a feature typical of the time, advised all foreigners in America to watch out for the symbols of the future:

A railroad, a penitentiary, a log house beyond the Mississippi, the last hotly-contested elections-things rather heterogeneous to be sure, and none of them at first glance, so attractive as the wonders of the old world-are in reality, and to him who regards them philosophically, quite as important, and as they connect themselves with the unknown future, quite as romantic. ${ }^{75}$

Here is the hope that new symbols-a railroad, for example-could take the place of the forest in expressing the freedom and the power of the new nation. Here once again is the expectation that Americans would build their city on the hill, that they would replace the great forests with a greater civilization. Even Thoreau felt this fever. In the roar of a railroad train he heard the promise which he knew would

74. 2 A. DETocQueville, Democracy iN AMERica 74 (1946).

75. ERRAND, supra note 56, at 211. 
not be kept. "When I hear the iron horse make the hills echo with its snort like thunder," he wrote, "it seems as if the earth had got a race now worthy to inhabit it." The disappointment follows immediately:

If all were as it seems, and men made the elements their servants for noble ends! If the cloud that hangs over the engine were the perspiration of heroic deeds, or as beneficent to men as that which floats over the farmer's fields, then the elements and Nature herself would cheerfully accompany men on their errands and be their escort. ${ }^{76}$

This is the dilemma which confronted the nation in the 19th century. Can the railroad train, the log house, the penitentiary, and the last hotly contested election express as well as do the objects of nature the ideals of national character and destiny? Do they represent a race whose deeds are so heroic and whose ends so noble that it is worthy to inherit a wilderness? Or are they merely the servitors of destruction, rapine, and luxury? You guessed it: the latter; and so the celebration of nature turned quickly to eulogy and lament. Nobody reads Cooper anymore-Twain's view of his writing is too accurate ${ }^{77}$ but in the 19th century, the Leatherstocking Tales, and the hundreds of dime novels modelled after them, provided a sort of elegy for the wilderness. Natty Bumppo, the hero of Cooper's romance, is, needless to say, everything the son of nature should be: strong, honest, innocent, just, a good shot, and so on. $\mathrm{He}$ is up against the force of civilization, cast in the form of Judge Marmaduke Temple, who owns most of the visible landscape and whom Bumppo respects, mostly because Temple has working for him the arts of law and theology. In short, it is the Siegfried legend, but in Western New York and during the Washington Presidency. ${ }^{78}$ Bumppo thus comes into conflict with a number of Alberics-the Skinners in The Spy and Ishmael Bush in The Prairie-who, by robbing the land of its wealth, attempt to set up an empire to rival the Judge's own. In one memorable scene from The Pioneers, Bumppo comes upon the frontierspeople massacring flocks of passenger pigeons by spraying them with buckshot from a cannon. The tall hunter responds as would anyone who values nature: a cannon, he says, suits “them that don't know how

76. H. Thoreav, Walden 116 (1971).

77. M. Twain, Fenimore Cooper's Literary Offenses, in How to Tell a STORY AND OTHER ESSAY'S 78 (1904).

78. G.B. Shaw, The Perfect Wagnerite, in Selected Prose of Bernard Shaw 204, 218 33 (1937). 
to put a ball down a rifle barrel, or how to bring it up again with a true aim; but it's wicked to be shooting into flocks in this wasty manner, and none do it who know how to knock over a single bird."70 When Bumppo is himself sentenced in connection with killing a deer in violation of the new game laws and eventually exiles himself to the prairies, no one could miss the point: the New World would take its manners and prejudices from the Old.

The conventional oppositions between the head and the heart, the city and the country, the guilty and the innocent, the past and the future, the dark and the blonde, the European and the American, the sublime and the beautiful-all of which are found in Leatherstocking and in the thousand romances that surrounded and imitated it-set the terms by which Americans in the 19th and 20th centuries have come to understand the expressive significance of nature and the environing wilderness. Anyone who wants can abandon these conventions. He can see, if he likes, the hand of God not in the woods, as Bumppo did, but in a parking lot. But if we wish to get some agreement about the expressive features to be found in our national landscape, if we hope to move from an arbitrary to an historically justified way of describing these things, then we must begin with a careful examination of the description available in our literature, religion, music, and art. As everyone knows, a single interpretation of our cultural history, indeed, of anything in it, will not emerge easily; works of art are open to an indefinite number of interpretations. This is the case, however, because we have not had any need so far to agree on a single line or a single direction of interpretation-as we have agreed, say, about weights and measures. After all, we are not a plantation of arts but a plantation of trades. The question of land policy, however, forces the issue. Historians of culture should put together the best sense they have, based on our literature and art, of the concepts we value and the objects which express these concepts. They may be surprised in this matter at the consistency of our cultural inheritance.

"Appreciation of wilderness," writes Nash, "began in the cities. The literary gentleman wielding a pen, not the pioneer with his axe, made the first gestures of resistance against the strong currents of

79. J.F. Cooper, The Leatherstocking SAga 681 (1954). 
antipathy." 80 The pastoral imagery of the South combined easily with the Biblical associations of the North; Arcady merged with Eden; the American was cast as Adam; and technology became the Edenic tree. Once again we stood at the dawn of civilization, as Emerson put it, "the plain old Adam, the simple genuine self against the whole world." 81 "And now," observes Adam in Hawthorne's The New Adam and Eve, "we must again try to discover what sort of world this is and why we have been sent hither." 82 It did not require the literary gentleman wielding a pen-or the artist-to find out that the new world was not heathen, cursed, desolate, or ungodly; it was, as anyone, even the foreigner de Tocqueville, could see, "the most magnificent dwelling place prepared by God for man's abode" and offered, as he said, "an immense booty to the Americans." 83 We did not need artists to tell us this. We needed our artists and writers to provide the litany of confession, in which Americans engaged to a ferocious extent during the 19th century, so that we could take hold of this immense booty without feeling too much guilt about the magnificent abode. Where a hundred years earlier there had been jeremiads, halfway covenants, and revivals, there were now novels, newspaper editorials, and revivals-and in the wake of the revivals came the courts. "The astonishing fact about this gigantic material thrust of the early nineteenth century," as Miller says, "is how few Americans would any longer venture, aside from their boasts, to explain, let alone to justify, the expansion of civilization in any language that could remotely be called that of utility." Miller continues: "The more rapidly, the more voraciously, the primordial forests were felled, the more desperately poets and painters-and also preachers-strove to identify the personality of this republic with the virtues of pristine and untarnished, or 'romantic' Nature." 84 Miller is right; writers, artists, and preachers not only exorcised the nation's guilt, but also recognized its responsibility; for while the nation saw nature as a source of prosperity, they experienced it, following the Puritans and the Jeffersonians before them, as a symbol of virtue as well. And so they had a purpose other than expiation; although the nation destroyed most of the wilderness, it had not done so frivolously. Nature

80. R. NASH, supra note 57 , at 44 .

81. R. EMERSon, Journat, quoted in R.W.B. LEWIs, The AMERICAN AdAM vi (1955).

82. 2 N. Hawthorne, The New Adam and Eve, in Mosses from an Old Manse 20 (1900).

83. I A. DeTocquevilie, Democracy in AMerica 19 (1956).

84. ERRAND, supra note 56, at 207. 
had been kept alive in the symbolism of art, literature, and religion, and in this sense, the nation had second thoughts. The contribution of artists, writers, and preachers from the time of Edwards to Melville to Fitzgerald and Faulkner was to discover in nature, then, the symbols of virtue, or, to be quite strict in the matter, to find in nature the attributes of God-His strength, intelligence, integrity-exemplified. It was to confront man with these attributes as ideals, and thus it was to compel him, as Fitzgerald wrote, "into an aesthetic contemplation he neither understood or desired, face to face for the last time in history with something commensurate with his capacity to wonder." 85 In thus describing what sort of world this is, our artists, writers, and preachers also told us why we had been sent hither: to conquer nature, surely, but to achieve also a national character which becomes it-so that our personality as a people will justify our prosperity and our prosperity will not have to justify our personality. How does this differ in any important respect from what Winthrop told his followers aboard the Arbella? The covenant is now with nature, no longer with nature's God, but this is a trivial difference. Since nature provides the best samples we have of the attributes of God, the terms of the covenant are the same.

The covenant we have with nature, which is as much an obligation to use well our natural environment as to preserve it-and, in any case, not to destroy it wantonly or in a wasteful manner-historically had religious rather than economic or even literary and artistic origins. Ever since Edwards in The Nature of True Virtue, published together with his Dissertation in 1755, defined true virtue as "benevolence" or "love for being in general" and distinguished it sharply from love or benevolence for the things which pertain to oneself, including beauty, family, country, and the like, ${ }^{86}$ we have been forced to recognize that our virtue as a people depends to a large extent on our benevolence toward our natural environment. But "benevolence" may be distinguished into two kinds. The first is the benevolence of Ben Franklin, a utilitarian in spirit, by the way; it is a willingness to countenance the interests of all creatures (except in the most inconvenient cases) against one's own. It asks "What good have I done today?"

Second, there is the benevolence described by Jonathan Edwards;

85. F.S. Fitzgerald, The Great Gatsby 182 (1953).

86. J. EDWARDS, Works 261-304 (1843). 
this benevolence respects things enough to let them be. It is not indifferent to suffering-pain should be relieved-but it would allow an animal to die, if to feed it would deprive it of its independence and strength. This kind of benevolence appreciates the character of things, and allows objects their own integrity by restraining the interference of man. This is a reverence for all things on which we might base an acceptable environmental policy: it respects nature enough to leave it alone.

This kind of benevolence does not reason in terms of benefits and costs; and it does not blush at the terms "guilt" and "responsibility." The killing of Indians was a crime, it says, even if they would all have died anyway and at the very next moment; and the destruction of the wilderness was also a crime, even if by some miracle it, too, would have been destroyed. This is not to say that our nation had a choice. Our national purposes may have required the devastation of the wilderness; and the death of the Indians. What benefits we received explain but they do not justify our acts; they may even add to the severity of the crime. The point would be to recognize our responsibility not only to what survives of the past but also to what we have destroyed. We had to act more or less as we did, but the recognition of what we have done-it is guilt-is a great resource to us: it provides a more human and more satisfactory motivation than does the simple pursuit of prosperity. Why does this sound strange? It is as old as Adam. It is the oldest thought in the world.

The responsibility to the wilderness is a recognition of its qualities both present and past; and it requires us to imitate these qualities. We wish to preserve these qualities where we can and to assume the character of that which we have destroyed. In Big Woods, Faulkner's hero Ike McCaslin, as a 12-year-old, goes on his first hunt and, following the direction of Sam Fathers, an Indian guide, kills a deer. Years later, McCaslin remembers:

I walked to the buck lying still intact and still in the attitude of magnificent speed and bled it with Sam's knife and Sam dipped his hands into the hot blood and marked my face forever while I stood trying not to tremble, humbly and with pride too though a boy of twelve could not actually have phrased it: "I slew you; my bearing must not shame your quitting life. My conduct forever afterward must become your death." 87

87. W. FAULKNER, BIG WoOdS (1955) (unpaginated, 6th page from end of text). 
"I believe," Thoreau wrote, "that Adam in paradise was not so favorably situated on the whole as is the backwoodsman in America." Then he added: it "remains to be seen how the western Adam in the wilderness will turn out." 88 This is the point. If he remains Adam, a utilitarian, an innocent, a backwoodsman, he will have his riches, his prosperity. Like Fitzgerald's creation, Jay Gatsby, he will have no history and no responsibility, but he will be in some respects a Titan, and he will fill with excitement many otherwise empty lives. "The truth was," Fitzgerald wrote, "that Jay Gatsby of West Egg, Long Island, sprang from his Platonic conception of himself. He was a son of God .... and he must be about his Father's business, the service of a vast, vulgar, and meretricious beauty." 89 The future, one imagines, is with Gatsby, not McCaslin. At the end of Faulkner's story, McCaslin, now 81, returned to the remnant of the woods along with a few younger people on his last hunt. On the first morning, his greatnephew, Roth Edmonds, shot two deer, both female, and therefore killed in violation of the law, and with buckshot, not with "the rifle which he had used ever since he had finally seen that a man with a steady eye and hand owed more to the bear or the buck than to shoot it with a blind handful of pellets." McCaslin, too sorrowful to be furious, manages to get the men to pick up the animals and feed them to the dogs-one doe was too old and tough for humansand he asks Edmonds why he used a shotgun. Edmonds replies with the innocence of the frontiersmen who defended to Natty Bumppo their use of a cannon. It is a utilitarian answer. "You said last night you want meat ...."90

Herbert Croly notes that "had it not been for ... the virgin wilderness, the United States would never have been the Land of Promise." He continues:

If its promise is anything more than a vision of power and success, that addition must derive its value from a purpose; because in the moral world the future exists only as a workshop in which a purpose is to be realized. . . . Only by a better understanding of the popular tradition, only by an analysis of its merits and difficulties, can we reach a more consistent and edifying conception of the Promise of American Life.91

88. Quoted in R. NASH, supra note 57 , at 90 .

89. F.S. FitzGerald, supra note 85 , at 99.

90. W. FAULKNER, supra note 87 (unpaginated, 3rd page from end of text).

91. H. Croly, The Promise of AMerican Life 6-7 (A. Schlesinger, Jr., ed. 1965). 
In other words: to know your policy, you must figure out your purpose; and to get your purpose, you have to know your history. Do not think, however, that a utilitarian policy is completely ahistorical. On the contrary, it is the outcome of a certain kind of history, that is, history written in a certain way. It follows from the economic approach to history-the epistemological or perhaps metaphysical view that considerations of wealth, power, comfort, and amenity must determine human action and the interpretation of events. This approach has not been limited to historians. Frank Norris and the American Realists in their novels and paintings anticipated Charles and Mary Beard. But then the conventions of history always reflect those of fiction; the Beards owe as much to writers like Norris as they owe to Marx. Similarly, Bancroft in the 1820's took his perspective from the pastoral writing of his own day, and so on through the history of history. If our literature at present has become psychoanalytic and associative, our historical writing has also changed. Treatises on the progress of bathtub manufacture in Rhode Island have yielded gradually to a large scale journalism of ideas. In the work of Perry Miller, undoubtedly America's greatest historian, and in that of Roderick Nash, Henry Smith, R. W. B. Lewis, Bernard Bailyn, Leo Marx, and scores of others, policymakers can find a more consistent and edifying conception of the American past-and therefore the basis of a more consistent and edifying conception of the promise of American life. ${ }^{22}$ Or they can obtain a sense of America's purpose by watching television and by seeing what is advertised in Time. The choice comes down to this: not what ideals we shall serve, because we know these-freedom, integrity, justice, intelligence, power-but what shall we mean by them? And this question is answered in our paradigms. The paradigm, the symbol, if you will, of freedom has been the wilderness, the deer, the bear, the eagle, a rapid river. It could be a washing machine or a coffee percolator. They can do five loads or make five cups at once -freeing the housewife from her tasks. In this case, freedom comes to leisure and power to efficiency. It's Gatsby's motor car: "the spontaneous fruit of an Edenic tree." 93 It's the shotgun pellets; it could

92. See, e.g., B. Bailyn, Education in the Forming of AMerican Society (1960); B. Bailyn, The Ideological Origins of the AMERican Revolution (1967); B. Bailyn, The Origins of American Politics (1968); R.W.B. Lewis, The American Adam: Innocence, Tragedy, and Tradition In the Nineteenth Century (1955); R.W.B. Lewis, The PicARESQUe SAint: Representative Figures in Contemporary Fiction (1958); R.W.B. LeWis, Trials of the Word: Essays in AMerican Literature and the Humanistic Tradition (1965); R. NASh, Wilderness and the AMERICAN Mind (1965); H. SMith, Virgin Land: The American West as Symbol and Myth (1950).

93. J. ORtega y Gasset, The Revolt of the MAsses 89 (1932). 
be the cannon. Our symbols of freedom could close with those of law and order; they may be the penitentiary and the machine gun. And they will change our understanding of the concept of freedom and strength. There is a threat here, and one which makes Winthrop's warning mild by comparison. And so the covenant analogy is complete. "This land," said the old hunter in Faulkner's story. "No wonder the ruined woods I used to know don't cry for retribution. The very people who destroyed them will accomplish their revenge." $9:$

94. W. FAULKNER, supra note 87 (unpaginated, final page of text). 


\title{
III. A Nonutilitarian Rationale for Preserving the Natural Environment
}

\begin{abstract}
A
Even if nature in the rough were beautiful, this would not be an adequate reason to protect it from development, for no one has shown that beauty has any value other than the pleasure it produces, and there is usually more pleasure in exploiting a natural environment than in leaving it alone. Nor has anyone shown that pleasure taken in beauty is better than less expensive enjoyments; indeed, it is difficult to know what "better" in this context could mean. The truth is often heard that to value a woman because of her good looks is to trivialize her, to ignore her more important qualities, and to regard her only as an object of use. It is likewise true of the environment. We regard nature only as a source of recreation if we do not see the difference between a wilderness and a pretty garden. We know the difference. Let us say what it is. The respect, reverence, and benevolence many of us feel toward nature and attribute to its beauty in fact is felt for its expressive qualities. A wild area may be powerful, majestic, free; an animal may express courage, innocence, purpose, and strength. As a nation we value these qualities: the obligation toward nature is an obligation toward them.

Suppose a big company proposes to build a ski resort on a mountain top in a national park; suppose, too, it intends to construct an access highway through an untouched forest. Let us assume, moreover, that the economic benefits of this proposal are great compared to the needed investment. The benefits, of course, would extend to wildlife and to the park itself. The denizens of the forest, for example, would be fed balanced meals by the management, and their cubs, or whatever, would be checked regularly by veterinarians; the bears would sleep on foam rubber all winter in quality-controlled dens, clown with the visitors, or possibly ski themselves. The developer will be quick to point out that without proper landscaping the terrain is rough, violent, and hostile. It is not really decorative; it is not quite beautiful. Artists usually provide relief to their landscapes by including some sign of human habitation-you can pick out a country lane or church spire in the distance. A landscape as vast as a national park, however, requires more than a country road to make it beautiful; it takes a
\end{abstract}


six lane highway to do the job. Few people go to church who also ski, but the rough terrain could be relieved by the graceful arches of a popular hamburger stand. And it will not cost the taxpayer a cent.

What can the environmentalist say? He can argue that the mountain will lose its fierceness, power and integrity. The wildlife will no longer be wild; it will forfeit its freedom and strength. There is no reason to think, however, that the animals value these qualities. Certainly very few people wish to confront nature on its own terms. They want an air-conditioned motel; they are glad to see the forest from a gondola after a drink. So what if they do not feel its cool hostility. Now environmentalists might begin to worry that they alone cherish the fierceness and power of nature and its integrity, or that only they and a few others value independence, power, endurance, sureness, and freedom as these are expressed by natural objects. The environmentalist will then despairingly point out that the development of a wild area, though increasing its amenity, destroys many of its expressive qualities. A protectionist policy reflects a concern with these qualities. It is justified by them and it may take on some of these qualities itself.

Let us suppose that the developer replies to this argument in the following way. A highway and a ski resort, he contends, are themselves symbols of power and freedom, not indeed the same kind of power and freedom that nature exemplifies, but the kind Americans really want. If someone reads our national literature, he might get the idea that the qualities of character Americans respect and seek are those expressed by objects in the natural environment; but this is the merest sentiment. Times have changed and the qualities we now value are symbolized by a fast pizza and a stick shift. A few snobs read books, and disagree about their meaning, but for the rest of us, who prefer magazines and watch television, the message is clear. The freshness and purity thought to be exemplified by a mountain stream now have a brand of mentholated cigarette as their symbol, and it is no longer a bear but a beverage which is wild and free. Power, as we now understand it, has nothing to do with nature. It is expressed by a hair tonic, perhaps, or by a detergent, or by a lot of engine under the hood. A century ago, natural objects were cheaper, and we could afford to use them as symbols. Now they are becoming scarce, and so we should accept a less expensive brand. Developed areas can take on the expressive function of untouched environments; the 
highway can replace the waterfall in our affection; the motel can take the place of the mountain.

The benefits of new symbols greatly outweigh the costs. Artificial trees can be advertised as symbols of life and integrity, and strip mines may be promoted as geological wonders-the view of the earth from the inside. Pollution exists only because we call it so; people would enjoy it if it were described as progress. The point is that we must stop attending to the literature, music, and art, written for an earlier century, which found in nature, then cheaper to preserve, the examples of important qualities. We should now believe our advertisers instead. When we realize that freedom comes with the right breakfast food, we will see that it costs much less than we expect (about 42 cents a day) to be free. From a cost-benefit standpoint you can't beat this. There is no reason that a ski lodge cannot be accepted as a symbol of all that we value. It is already. We can have our development and our aesthetic enjoyment, too.

The developer need not reply to the environmentalist in such an uncompromising manner; he could also answer in a softer way. $\mathrm{He}$ could agree with the environmentalist that nature does possess important aesthetic qualities, that it expresses freedom, purpose, and strength, for example, and that natural objects are more appropriate paradigms of these qualities than are breakfast foods and kitchen appliances. Accordingly, he might concede that the country has some stake in preserving or at least respecting the expressive qualities of nature, even if he is not sure what this stake may be. The developer might declare his willingness, then, to protect the aesthetic qualities of the environment as he understands them and wherever they do not simply prevent development. He might promise, for example, not to domesticate wildlife; either the animals will die or have enough room to preserve their strength and independence by fending for themselves. He might also decide not to build a pleasure palace for rich people whose only need is to amuse themselves. Nature should not be an idle spectacle; therefore he will build an arduous ski area where people will have to confront the mountain somewhat on its own terms and do rather more for their pleasure than throw a beer can out a car window. Visitors would come, then, with respect for the mountain, not to disgrace it after it has been subdued by machinery, but themselves to conquer it. In these and other ways, the developer could compromise with the environmentalist. But he must know how to determine the aesthetic qualities of various environments. He wants 
to understand why these qualities are so important, especially since they are often the ones which make nature least pleasant, and he needs to understand how to preserve them in a development. The problem of the symbolic aspect of nature is an important one, and it should be stated clearly and correctly.

The following pages attempt to explain the aesthetic value of natural environments. We consider only the expressive qualities of these environments and not their beauty, considered formally, or their amenity, about which enough has been said. We begin, then, by defining the expression "aesthetic quality." An "aesthetic quality" is any quality named in a metaphorical way. The distinction between the nonaesthetic and the aesthetic and the distinction between the literal and the metaphorical coincide. The distinction between the objective and the subjective is logically independent of the other distinctions: thus, a metaphorical or aesthetic quality can be objective as well. A brook, for example, may be "laughing" and "wet" in exactly the same way. Once we have these distinctions properly before us, we can understand the definition of "expression": if an object expresses a quality, that quality is metaphorical, the object possesses the quality, and the object exemplifies the quality. ${ }^{95}$ Thus objects are examples or paradigms of the qualities they express. Now, paradigms have a cognitive function; they provide samples by which we learn to recognize given qualities. Change the paradigms of "freedom" and you change your understanding of what it is to be free. Thus, the question of substituting one symbol for another, and therefore one paradigm for another, is a very tricky one. It involves a change in the objects we recognize as having the quality; in other words, it changes the quality itself.

After we establish all this, we move on to determine the aesthetic qualities of nature and the natural environments to which they belong. The criterion here is our cultural history, not our advertising, and the reason is not hard to find. The business of the arts is to provide expressive objects and to represent other objects as expressive; therefore, art objects are themselves paradigms of aesthetic qualities and they represent other objects as paradigms. Just as the sciences have, the function of describing the theoretical properties of things, so the arts determine, by way of providing crucial examples, aesthetic qualities. The arts, no less than the sciences, describe a way the world is. This is the cognitive function of art.

95. See note 70 supra. 
Having said this much, we defend it against one objection, viz., disagreements about the aesthetic properties of objects of art and nature seem to show that these properties are not objective but belong to the subject's response. This objection is not compelling; after all there can be disagreement as well about commonsense and theoretical properties. The important thing is that we have conditions for determining at least in principle when a description-aesthetic, commonsensical, or theoretical-is true or false. These conditions will be stated for the aesthetic description of nature and art.

\section{B}

An "aesthetic quality" is any quality named by a metaphorical predicate. Here are some predicates: "is laughing," "is sad," "is empty," "is free." Each of these can be used in a metaphorical and in a literal sense. When we attach the predicate "is laughing" to the subject "Mary," the predicate is used literally. Attaching it to the subject "the brook" gives us a metaphorical description. There are occasions in which a term can be predicated of an object both literally and metaphorically; then we have to determine by the context which is meant. To say that Mary is empty, for example, may characterize her personality (the metaphorical use) or assert that she has not eaten anything (her stomach is literally empty)-and one description may be true while the other is false. The difference between the metaphorical and the literal use of predicates is a matter of conventionality: the literal is the more usual, habitual, or familiar use. As a rule, metaphorical terms are transferred from their routine or literal realm of application-say, sentient beings-and applied to objects which they do not conventionally describe. Thus, when we say that a river is happy or that a mountain is hostile, we do not mean that either has feelings; we are using predicates that habitually describe sentient beings to describe inanimate things. A family of predicates has been transferred from a conventional to a less conventional realm. This is the characteristic of metaphor. A predicate which is used in a metaphorical way describes a metaphorical quality. And whether we say "metaphorical quality" or "aesthetic quality" we are talking about the same thing.

The aesthetic qualities of nature are just those qualities which are described in metaphorical terms. These terms, or predicates, very often have human beings in their literal realm or extension. When we find nature to express a metaphorical quality-e.g., freedom-it is 
often a quality which we literally may possess. Thus there is a connection between the ways we describe and therefore understand and experience nature and the ways we describe, understand, and experience ourselves.

In spite of the fact that the aesthetic is easily defined, as we have defined it, without any reference to the subjective, people have thought that aesthetic judgments must be or usually are subjectiveand this is a mistake. Aesthetic qualities can be objective. The statement that a mountain is hostile or noble is as much a factual description as the statement that it is tall and in Spain. This is not to say, of course, that mountains are literally hostile or noble. On the contrary, they do not have feelings nor descend from noble blood: rather, the terms "hostile" and "noble" are used as they apply to inanimate objects and not as they apply to human beings. This use of these predicates is unconventional, of course, but not arbitrary; it is unusual, but still true or false. Metaphorical properties are not routinely ascribed to mountains, but they are correctly or incorrectly ascribed to mountains; they are actual properties nonetheless.

Why have people thought otherwise? Why is it common to believe that aesthetic descriptions are not objective but express only a subjective response? The reasons seem to be three. First, some people have thought that the aesthetic value of nature and art consists in the production or transmission of emotion in or to an audience. On this theory, a river is "happy" insofar as it causes those who see it to feel happy merely by seeing it, and a painting is "sad" insofar as it makes those who perceive it feel sad. The receipt of these emotions, on this view, explains part of the purpose of art. This theory does make aesthetic judgments subjective. Neither the mountain nor the canvas would be the logical subject of the emotional qualities. They would cause these qualities, and the subject would be the spectator himself. Second, some people have also believed that the sadness and the happiness belong as properties neither to the object nor to the subject but to a special kind of subjective or "phenomenal" entity that exists "in" experience or "in" the imagination. If this view can be understood at all, it also seems to make aesthetic qualities depend upon subjective response. Finally, the fact that people disagree concerning the aesthetic qualities they find in things also suggests that these qualities may belong or be logically tied to the subject more than to the object of experience. Since aesthetic descriptions are by 
definition unconventional, however, disagreement of this sort is to be expected. Nevertheless, it does raise the question whether principles for resolving such disagreements can be found.

Because these "reasons" for believing that aesthetic judgments are subjective are so widely held and respected, we shall pause to refute them. In doing so, we do not prove that aesthetic judgments and qualities are factual-only that certain reasons for believing otherwise are false. The argument for thinking that they are factual will be given later. Throughout the discussion, we shall use examples drawn from nature and from art. There is no difference between them in respect to the theory advanced here, and sometimes a painting is a less unwieldy example of a principle than is a forest or a mountain.

The belief that the function of art consists primarily in the production of emotion, although it is popular, is ludicrous. Of all art, soap operas, on such a view, become the most important, but even they are outdistanced by a roller coaster, a Baptist revival, or even a good family fight. The fact is that only preadolescents have energy for emotional thrills, and this explains their interest in hard rock; you appreciate peace and quiet after 25. Accordingly, it is hard to understand why an object that stimulates emotion is valuable; it would seem to be the very thing to avoid. Empathy with others, of course, is sometimes morally desirable, but for this art is no help to us. The variety of emotions with which people respond to well known works suggests that they use the occasion to feel whatever is in their own hearts and not the hearts of others. Accordingly, there can be therapy in this sort of response-we all like a good ghost story-but there is no understanding of the value of art.

It is not hard to refute the view that nature and art function aesthetically to cause pleasures and emotions in us. We need only to distinguish the emotional quality of the spectator from the emotional quality of the work. In order to recognize the passionateness of the painting the perceiver need no more become passionate than to recognize the colors of the painting he need turn red and green. This is not to deny, by the way, that the experience of a painting or of nature is emotional: we can feel that the painting is passionate just as we can feel that a person in a metaphorical sense is warm. To do this we need not ourselves become passionate or warm. We can act in the context of cognition rather than that of stimulus and response.

Of all theories of art which make it the cause of a feeling, the most heady, no doubt, is the "Formalist" thesis that "there is a particular kind of emotion provoked by works of visual art, and this ... emo- 
tion is called the aesthetic emotion." 96 While the Formalists did not extend this hypothesis to nature, we could easily do so by holding that nature, too, proffers a special "aesthetic emotion." Clive Bell, the most vocal of the Formalists, announced that "to appreciate a work of art we need bring with us nothing from life, no knowledge of its ideas or affairs, no familiarity with its emotions." ${ }^{0 r}$ Art, then, is supposed to be entertainment for the senses, when the mind is empty. But what is this "particular emotion" and why is it valuable? Needless to say, the emotion is defined in terms of the "significant form" of the painting, and vice versa, thus describing a circle, which also provokes an emotion. It need not detain us that Bell characterizes aesthetic pleasure as an ecstasy or as an exaltation, for this is said by the drunkard about alcohol, the seducer about fornication, the addict about heroin, the miser about money. They are all voluptuaries, each praising the consciousness-expanding properties of his drug. And there is no evidence that the aesthete is in fact any better for his pleasures than if he had sniffed the paint instead of looked at it. Nor need it bother us that the Formalist view makes most art before Cezanne inconsequential. Objections such as these are too easy to make, but they do teach us to avoid one perspective.

The purpose of art is not to give us a special tingle. That is the purpose of a massage. Nature and art are not mere stimuli to which we respond with an emotion or a feeling of pleasure; they contain symbols which our perception and our tradition allow us to recognize and understand.

This brings us to the second objection against our view that mountains are actually (though not literally) noble and that paintings are actually (though not literally) sad. According to this objection, aesthetic predicates used in talking about art and nature are ascribed neither to the subject of aesthetic experience nor to the physical object-i.e., the canvas and the mountain-but to something in between: a "phenomenal," "perceptual," or "aesthetic" object which exists "in" experience or "in" the imagination. The reason for so strange a suggestion is this: the aesthetic or metaphorical properties appear to be caused by the literal ones or are dependent on them in some strange and inexplicable way. If this is so-if the aesthetic properties

96. C. BELl, ART 6-7 (1958).

97. Id. at 25 . 
have some actual, let us say, metaphysical, dependence on nonaesthetic ones, if they are caused by them, for example-then it might not be easy to believe that they belong to the same object or indeed that they belong to that object in the same ways. If a painting is not passionate in the same way that it is red and green, then it may not be the same thing which is red, green, and passionate. Hence "aesthetic objects" and other creatures of the perceiving mind.

But why would anyone suppose there is a causal or other such relation between literal and metaphorical properties? What suggests that a painting, or a meadow, is not green and passionate in the same way? The green is a noticeable quality of the painting. But so is the passion. Like many aesthetic qualities, it is formal, a certain congruence or relation of shapes and colors which you notice when someone points out that the painting is passionate. That some of the green color "enters into" the passionateness of the painting means little; after all, as much of the passionate quality also "enters into" the green color. They overlap. But this no more means that the passion is caused by the colors than that the colors are caused by the passion. To describe a painting as "passionate" is not to describe it in a conventional way, but this has only to do with the history of the predicate. The description, then, is less routine than, but not justified by, a literal description. The painting is not passionate because it is red and green.

People are apt to think, however, that there is a causal relation between aesthetic and nonaesthetic properties because of the quasicausal terms in which we describe works of art. The following expressions are typical:

"it is the handling of meter and caesura which is responsible for its strength and variety," "its nobly austere quality is due to the lack of detail and the use of a restricted palette," "its lack of balance results from the highlighting of the figures on the left," "those minor chords make it extremely moving," "those converging lines give it an extraordinary unity." 98

There is nothing wrong with any of these statements. They explain or call attention to the unfamiliar by describing the familiar, much as you would point out a well camouflaged insect on a leaf. These statements get us into trouble, however, because they suggest that the

98. Sibley, Aesthetic Concepts, in Art and Philosophy: Readings in Aesthetics 361 (W. Kennick ed. 1964). 
aesthetic qualities are causally dependent upon the nonaesthetic ones. But all these statements are reversible in a sense in which causal statements are not. From the metaphysical point of view, that is to say, they would be equally acceptable if they went the other way. Thus we might say that the strength and variety of a work is responsible for its meter and caesura. The only reason this sentence sounds odd is that we usually put the more conventional description of an art work in the antecedent condition and write the less familiar description as the consequent. A community of aesthetes would do the same thing; they, too, would explain the less in terms of the more familiar. But since they are aesthetes, while we have a plantation of trades, the properties familiar to them would reverse ours, as likewise would their noncausal explanatory sentences. We might argue that "The Stars and Stripes Forever," when played fast, has a triumphant character; played slower with less rhythmic exactness and emphasis, it sounds less triumphant. And from this we would conclude falsely that the triumphant character is causally dependent at least in part on tempo and other dynamics. The aesthetes, who always describe music according to its mood and know nothing about tempo, will reason just the other way. And they will conclude that the tempo is causally dependent, at least in part, on the lessening of triumphant character. Clearly, these are not cases of causal dependency. They are conceptual, heuristic, pedagogical explanations. No general causal relation exists between the aesthetic and nonaesthetic qualities of nature or works of art.

Consider another example. This page is oblong and it is also straightedged. It would not be oblong unless it were straight-edged, and, assuming it keeps its other properties, it would not be straight-edged unless it were oblong. You could say, depending on your purpose, that the page is oblong because it is straight-edged or straight-edged because it is oblong. If you were teaching someone to recognize oblongs, for example, you would explain that this is an oblong because, among other things, it is straight-edged. But if you met someone who did not know the meaning of the term "straight" but recognized oblongs (there is nothing impossible about this), you would tell that person that this page is straight because it is an oblong. The relation between the equiangularity and equilaterality of triangles may provide a better example. Similarly, you might say "this is a Lamborghini and not a Maserati because it has this shape" or "this has this shape because it is a Lamborghini and not a Maserati." This sort of explanatory dependence of one quality on another is reversible. It proceeds simply from 
the more to the less familiar as determined by the context. Causal relations, presumably, are not reversible in this way. Accordingly, not all explanatory dependencies are causal or even quasi-causal dependencies. They may only draw attention from the more to the less noticeable details. This is the case in respect to the aesthetic and nonaesthetic qualities of nature and art.

The problem of resolving disagreements about aesthetic qualities is now the only objection in the way of regarding these qualities as actually belonging to things. A principle is easily provided; we shall get to it further on.

Expression is defined as the exemplification of a metaphorical property. Examples are paradigms. Thus objects provide paradigms, and in that sense are symbols, of the qualities they express.

This definition of expression follows closely that announced by Nelson Goodman. "In summary," Goodman writes, "if $a$ expresses $b$, then: (1) $a$ possesses or is denoted by $b$; (2) this possession or denotation is metaphorical; and (3) $a$ refers to $b . " 99$ For reasons we need not go into here, Goodman prefers to speak not of qualities, such as passion, heaviness, or sadness, but of predicates, such as "is passionate," "is heavy," "is sad." There is no trick here: after all, something is heavy if and only if the label or predicate "is heavy" correctly describes it and so on for every property and every predicate. We identify the properties of things, then, insofar as we sort them under predicate schemes. We identify color, for instance, by means of the schema "red," "orange," "yellow," "green." We say that the objects to which a label is correctly applied constitute the extension of that label, and the label denotes every object in its extension. Now we can understand Goodman's definition. If a painting, for example, Van Gogh's Night Café, expresses a quality, in this case, passion, then it possesses that quality-the painting is passionate. Goodman prefers to say that the predicate "is passionate" denotes (among other things) Night Café. So much for part one of the definition. Part two says the property is not literal but metaphorical: the predicate "is passionate," which denotes sentient beings literally, metaphorically denotes Night Café. This is the case because paintings do not belong to the conventional realm of predicates of mood or feeling: after all, they are not sentient beings. Part three of the definition requires that the paint-

99. N. Goodman, supra note 70, at 95. 
ing not only be passionate, but also serve as a sample of that quality, much as a tailor gives you a sample to exhibit the qualities of his cloth. Thus, if Night Café expresses the terrible passions of humanity, it exemplifies whatever is passionate in that terrible human way. Exemplification is a kind of reference; thus, while the predicate "passionate" denotes Night Café, the painting refers back to the predicate. In this way, aesthetic objects, whether of nature or of art, are conventionally used as paradigms and therefore symbols of the metaphorical properties they possess. A paradigm is a sample, and samples permit you to recognize new instances of a quality. More technically, samples guide your projection of labels to objects in the world. If a deer is an expressive symbol of freedom, then, it is used as an example of freedom; it helps to teach the meaning of "freedom" and to show what things are free. There are many predicates, e.g., "powerful," "noble," "passionate," "happy," about the proper projection of which we disagree. But often we work an agreement out by considering as examples of these qualities certain objects of nature and art. We might say, then, that the novel Huckleberry Finn exemplifies defiance. Where we agree that metaphorical qualities are exemplified, we also find them expressed.

Paradigms make conspicuous certain of the similarities and differences among things. They guide and to an extent justify our description of these similarities and differences. Paradigms exemplify schemata of sorting predicates; they provide a precedent for the ascription of these predicates; thus they determine and to an extent justify the projection of these predicates to the world.

The problem of knowing something about the world is often the problem of determining which objects are different and which are the same. But any two objects have an innumerable number of similarities and differences-even if they are peas in a pod-and among the objects in any collection the similarities and differences are practically infinite. This problem is resolved by our language. We have a limited vocabulary for describing similarities and differences, and insofar as the labeling schemata we use have become conventional and authoritative, they describe the important ways in which objects differ and are the same. Consider color. The schema of color labels in use determines whether we describe two objects as red, and thus as having the same color, or as crimson and cherry, and therefore as different. To teach an American to recognize the color white, you 
would not only give him a sample of that color, but examples of other colors, so that he can see what differences as well as what similarities count. An Eskimo would require quite different paradigms. White is not a color for him; what we call "white" is a variety of colors. He uses a labelling scheme, then, which discriminates colors as different which we describe as the same, and, in respect to reds, his labels may lump colors together which we conventionally discriminate. The differing ways of describing things obviously are conditioned by our needs. Now, we need to distinguish not only among kinds of color but kinds of life style. We need labelling or classifying predicates for personalities, ethnic groups, cloud formations, illnesses, golf clubs, law cases, articles of furniture, and most other things. There are rarely definitions which determine how these things are classified, and where these have been devised, they usually follow and in that sense canonize convention. Instead of definitions, we use paradigms to understand the crucial differences among things and the similarities. A good paradigm, then, is a discovery: it tells you how the world may be known by showing you how it can be described.

So far, we have considered the matter abstractly; we shall now look at examples. Suppose you describe a person you know as "empty." Not literally empty, of course, but empty nevertheless. He is empty and unhappy. One property is metaphorical, the other literal. Notice, incidentally, that the metaphorical property does not depend on the literal one; the causal connection, if any, goes the other way. In any case, you want to help him, to fill his emptiness. But what is "emptiness" in this sense and what can you do for people who are empty? The first thing that comes to mind is the possibility of finding out if there are any similar cases, other empty people who have been helped. Your friend, however, is not a well-known case; accordingly, you wonder whether there is anyone sufficiently like him whose emptiness people have understood. Hedda Gabler might come to mind. This play might make you change your original description of emptiness or understand more clearly what it meant. You might think of other qualities which are in the same "family" as emptiness. Other art objects may come to mind which exemplify these attributes. Insofar as they express these qualities they help you to understand them. They give you new ways to describe and compare people, and so they help you to describe and therefore to understand your friend.

Let us push the example one more step. The terms "psychopath," "neurotic," and "schizophrenic," although very elastic, do not yet take care of everyone. Accordingly, psychologists might look for other 
taxonomic labels by which to identify personality types. "Empty" might be one of them. The problem of taxonomic innovation sends us searching for metaphorical predicates. And a new science will move easily between metaphorical and theoretical terms. Thus a psychologist may describe us as "depressed," "introverted," "well rooted," "unbalanced," "empty," "lacking identity," "brainwashed"; yet each of these descriptions is either inappropriate or false in its literal sense. The literal use of these terms, however, gives us something to go on: the application of "empty" and "full" to bottles suggests ways we can project them to human beings. But we clearly need more than that. If metaphorical labels are to be used theoretically, they must be made more precise. One way to make them more precise is to supply them with necessary and sufficient conditions in literal terms. If we had the requisite literal descriptions, however, we would not have been forced to metaphor. But we may be able to provide samples or paradigms by means of which we can reach an agreement about alternative metaphorical taxonomic predicates. Thus we provide case histories. Freud, for example, tells a story about somebody and says this is a case of hysteria. And you have to agree or disagree about this case and that. Eventually, if a large majority of professionals concerned with a classification learn to project it to new instances in roughly the same ways, the classification becomes literal, however metaphorical its origin.

Now it makes no difference whether the case histories which make up the samples or paradigms for a taxonomy are factual or fictional. They need only function along with other case histories as a group of samples which exemplify labels so well that, on the basis of these samples, professionals can project labels in more or less the same ways. Their epistemic function is not to test anything but only to exemplify how things are classified. Very often the best paradigms for theoretical taxonomies can be found in the arts. Meteorological classification of cloud formations, for example, consciously follows artistic conventions. Returning to our example, surely we find in Hedda Gabler as fine an example of emptiness as one could wish. And in Hester Prynn we discover the paradigm of just the opposite quality, integrity. Sometimes a play, painting, or story offers so striking an example of human character that it becomes a label itself.

In providing paradigms of aesthetic qualities, the objects of nature do not differ in principle from those of art. Qualities of the sublime -those associated literally with God-are among these qualities found exemplified in natural things; might, integrity, justice, purpose, peace- 
fulness, tranquillity, patience, love, intelligence, wrath, and so on have well known symbols in nature. Our ability to experience these qualities as they are exemplified in nature is also an ability to identify them in our own actions, or in those of a nation, and to use them as ideals with which our more familiar notions of these qualities can be compared. We cherish and respect art objects, in part, because they give us this knowledge; they exemplify properties which we most need, or have needed, to recognize and to understand. Similarly, we cherish objects of nature because they, too, exemplify qualities which we find expressed nowhere else. And these qualities, particularly those which have theological or religious interest, are enormously important in our culture. Accordingly, many people feel the same way about the destruction of a very great painting as they do about the destruction of a magnificent natural environment. In losing either, we lose the best example we have of a quality which we do not otherwise fully understand or on which we have no better grasp. The destruction of symbols is a step toward ignorance of the qualities those symbols express. ${ }^{100}$

We can now return, with more understanding, to the problem of showing the factual nature of aesthetic properties. There is a prejudice, as we have been, that the sky, for example, is not foreboding in the same way that it is grey, and not grey in the same way that it is full of particulates. This belief is false. These are all simple properties of the sky. None need be subjective. Each represents a different interest, a different context of discovery. It is the kind of description -each having its own history-which is not the same.

Now, to put this discussion on firmer ground, it is helpful to understand that the relation of the aesthetic to the commonsensical description of the world has much in common with the relation of the commonsensical to the scientific. Each context of description sup-

100. Another alternative would be to change the nature of our cultural heritage. One imagines a four lane highway painted through Christina's World; or perhaps, To him who in the love of nature holds

Communion with her visible forms, she has

A recorded message; for his gayer hours

She has a sound and light show; and a place

or,

To muse beneath a billboard....

A child said What is the astroturf? fetching it to me with full hands

How could I answer the child? I cannot pay for it any more than he. and inevitably,

I guess it must be the flag of my disposition, out of hopeful fiberglass woven....

Poems are made by fools like me,

But only Union Carbide can make a tree. 
plements, and none replaces, the other. An example will bring out the point. Suppose there were a fellow who had scientific scanning equipment-oscilloscopes or spectrographs or whatever is needed-by which he senses the microscopic textures in the surfaces of things. And suppose this fellow speaks the language of an advance scientific theory rather than that of common sense. He talks about surface molecular structures with his friends and sees things as only someone with oscilloscope senses can. One day he and his friends decide to work out a theory of their own perceptual behavior-to find out what it is about objects that accounts for perception. So they capture some human beings to use as instruments by which to measure objects as they really are. The humans see things and tell their captors about the colors they see. Naturally, the oscilloscope people would come to think that their own personal descriptions are merely subjective and that things are actually red and blue and green.

Now the mistake is obvious. The experimental psychology developed by oscilloscope people does not show that their descriptions of nature are subjective. It only presents a theory of how their senses function. Similarly our experimental psychology does not show that what we see is subjective. It is only a theory of how we work as measuring instruments. ${ }^{101}$ Both the oscilloscope description and the human description are perfectly objective and perfectly compatible. Both are based on finely calibrated instruments and conventional frameworks of justification and criticism. There are not two different worlds, one subjective and one objective, but one world which can be described in two different ways. Now, the media of the arts have much in common with the instruments of physics, and the symbol systems of painting, music, and poetry are as conventional and highly refined as those of any of the sciences. The arts reveal metaphorical, or, if you prefer, aesthetic qualities. These attributes belong to the same old world as do theoretical and ordinary commonsense properties. Thus there are at least three, not two, ways this one world is to be described. Is there any wonder, then, that artists, like scientists, say they make discoveries about a way the world is? "Painting is a science," said Constable, "and should be pursued as an inquiry into the laws of nature. Why, then, may not landscape painting be considered as a branch of natural philosophy, of which pictures are the experiments?"102

101. The thoughts presented here are the author's reflection on the ideas of Nelson Goodman. See generally N. Goodman, The Way the World Is, in Problems and Projects (1972).

102. Constable, Lecture at Royal Institution (1836), quoted in C. LesLiE, MEMoIrs of THE Life OF JoHN CONSTABLE 323 (1951). 
Someone may object that almost every work of art can be interpreted in a great variety of ways. If this is so, there seems to be no method to agree on which aesthetic properties a work expresses. Without reaching such an agreement, however, how can we consider an art object to be a paradigm of any quality and how can we use it as a basis for an objective description of the aesthetic properties of other things? This objection is easily removed.

Let us state the objection in precise terms. It is obvious that when we take a work of art outside of its conventional class of comparison, we find that it can be interpreted in a thousand different ways. Van Gogh's Night Café can be seen as having a lot in common with works of the "homey" Dutch indoor school. It appears to be calm and peaceful rather than passionate when we keep these paintings in mind. And the Mona Lisa has been thought to exemplify every period, style, and emotional quality in which a critic has been interested. The interpretations of this painting, as of many other paintings, have been so various and incompatible that it is hard to believe that what is on the canvas has remained the same. ${ }^{103}$ Perhaps the problem in respect to the visual arts is best put by E. H. Gombrich in this description of the different aesthetic qualities which can "appear" in Mondrian's well-known painting, Broadway Boogie-Woogie. Gombrich writes:

In most of us the name of Mondrian conjures up the expectation of severity, of an art of straight lines and a few primary colors in carefully balanced rectangles. Seen against this background, the boogiewoogie picture gives indeed the impression of gay abandon. It is so much less severe than the alternative we have in mind that we have no hesitation in matching it in our mind with this style of popular music. But this impression is in fact grounded on our knowledge of the restricted choice open to the artist within his self-imposed discipline. Let us imagine for a moment that we were told the painting is by Severini, who is known for his futuristic paintings that try to capture the rhythm of dance music in works of brilliant chaos. Would we then still feel the Mondrian belongs in the pigeonhole with boogiewoogie, or would we accept a label calling it Bach's First Brandenberg Concerto? ${ }^{104}$

103. Cf. G. Boas, The Mona Lisa and the History of Taste, in Wingless Pegasus (1950).

104. E. Gombrich, ART and Illusion: A Study in the Psychology of Pictorial RepREsentation 369-70 (Mellon Lec. in Fine Arts, Series 36, No. 5, 1956). 
The problem does not stop with the fine arts: Lear, for example, loses its tragic character, as Jan Kott has shown, ${ }^{105}$ and appears to be a drama of the absurd, if we but assume Beckett wrote the play. Moby Dick has strong ties with Calvinism and Transcendentalism when read in the context of Hawthorne and Emerson, but it has a very different mood in comparison with Russian novels. Now, we cannot say that these works have all the qualities they appear to have, for this would bury this distinction between objective description and personal response. And some of the qualities these works are thought to have, e.g., the homey quality and the terror of the Van Gogh, are not even compatible-if we assume that metaphorical ascriptions are "incompatible" when contradictory in their literal use. These problems raise the question of which aesthetic qualities art works really have. Unless this question can be answered, we will not have a nonarbitrary aesthetic description of works of art. We could hardly use these works, then, as paradigms for an aesthetic description of the world.

The fact that there is disagreement concerning the aesthetic qualities of art objects does not show that these qualities are personal or arbitrary; it merely raises the question of how these disagreements are to be resolved. There are similar disagreements, of course, about the theoretical and commonsense properties of things; and yet these qualities obviously belong to the object. It is not clear how differences arising in science are settled; that is a matter for the philosophy of science, not for us. Controversies about ordinary qualities, however, are resolved by calling in better witnesses or by improving the perceptual conditions, for example, the light. An object has a commonsense property if and only if it appears to have that quality to adequate observers under standard conditions. This criterion for commonsense qualities, however, works for aesthetic qualities as well. There are likewise "adequate" observers and "standard" conditions for the interpretation and description of works of art.

There should be little surprise that an orange appears gxeen, or whatever color, under a strange light; similarly, there should be no surprise that Mondrian's painting takes on a peaceful quality when seen in the "light" of a Severini. If you compare Lear with Godot, it is bound to reflect some pretty weird qualities, as will Moby Dick, when we look for the properties it-has in common with the Russian novel. The fact is that there are perfectly standard and conventional classifications, historically based, in which paintings, novels, sym-

105. J. Kott, Shakespeare OUR Contemporary (1964). 
phonies, and other works of art can be compared and understood, and there is no need, other than fashion or amusement, to interpret art works outside these categories. It is entertaining to do so. It sometimes provides an audience with a quick rush of feeling or enjoyment. But insofar as the "audience" is not a few people who perceive an entertainment presented in an unusual context, but a nation or a society which needs to use its cultural history as a guide to its own character and policy, a more definite criterion than the whim of a director or a critic can be found. This is the work of historical scholarship. The style, genre, period, and other classifications in terms of which historians conventionally regard works of art may be taken as standard; and aesthetic description is relative to historical classification in this sense. The more historical information which can be brought to bear on interpretation, the better. And while this information in some cases can itself suggest alternative possibilities, it also presents many areas and issues on which historians not predisposed to defeat each other can agree. Interpretations of art objects which place them within the limits of their historical and cultural contexts do not, admittedly, provide the thrill or the satisfaction of other interpretations-sometimes things appear more interesting under a strange light. Insofar as art objects serve as paradigms for the recognition of aesthetic properties, however, the audience is universal, and the criterion, therefore, historical. Without a historical basis of comparison-an art history which is the counterpart of the history of science -it is difficult to see how there could be a cognitive function of art.

A proof of the theory of the cognitive function of art, incidentally, is that it alone makes sense of the notion many people cling to that a reproduction is not "as satisfactory as" an original work of art. Those people are right, we now see, because paintings are to be compared with others of their own kind. More important, copies may serve to remind or teach us what an original painting discovered, but the cognitive importance of that painting is found within its historical context. We could say the same thing of any poem, play, or scientific discovery. Thus, the problem of reproduction in art is to be understood on analogy with experiments in science. No more is accomplished by repainting a painting than by repeating an experiment for the second time. The interest is heuristic or pedagogical; from the aesthetic or theoretical point of view, nothing is gained. We admit, of course, that a reproduction can deliver as big a thrill, pleasure, or tingle as an original. We are speaking only of the cognitive function of art. 
Here is a summary of what we have now said. First, since symbols are paradigms of the qualities they express, they enter logically into our determination of the same qualities in other objects and events. They are the sample cases against which new possibilities are tested. Second, since the arts comprise the disciplines in which expressive symbols are themselves created and criticized, they give us the context in which aesthetic properties are discovered. The arts, in other words, permit metaphorical description to be factual and cognitive, much as the sciences provide the context appropriate for the use of theoretical terms. This explains the logical connection between our cultural history and our environmental policy. We should follow the instruction of our literature, music, and art in determining the aesthetic qualities of our environment much as we follow advice of the sciences in working out the technical problems of our policy. The difference between our literature and our commercial advertising, then, is the difference between a doctor and a snake oil salesman. Finally, the cognitive function of art, particularly the projection of metaphorical labels from art objects to the world, demands some convention concerning how art works themselves are to be metaphorically described. Since the interpretation of works of art becomes chaotic only when it takes them out of their normal art-historical or art-theoretic classes of comparison and criticism, it seems overwhelmingly plausible that we ought to use the conventions we have.

C

Earlier this century, conservationist groups argued with some success that governments should protect the national environment from excessive exploitation in order to safeguard and, by proper planning, to increase the benefits nature offers man. These conservationists wished to save the goose-but primarily for the sake of the golden egg. Today, environmentalists have come to see the inappropriateness and futility of this kind of argument. The argument is inappropriate because it distracts attention from the real motivation of the ecology movement, which is not to derive economic or recreational benefit from nature so much as to respect it for what it is and therefore to preserve it for its own sake. And the argument is futile, as we have said, because utility is generally to be gained by changing natural environments, not by preserving them. Accordingly, a different and, indeed, a nonutilitarian rationale is needed to support protectionist policies. This paper proposes such a rationale. 
Our proposal is this: We have an obligation to protect natural environments insofar as we respect the qualities they express. We have seen that these qualities do actually belong to some environments, which are their paradigms; and the discovery or identification of these qualities is effected in our language and by our arts. Preserving an environment may be compared to maintaining an institution, for symbols are to values as institutions are to our legal and political life. The obligation to preserve nature, then, is an obligation to our cultural tradition, to the values which we have cherished and in terms of which nature and this nation are still to be described. It is difficult and indeed unnecessary to argue that fulfilling this obligation to our national values, to our history, and, therefore, to ourselves confers any kind of benefit; perhaps fulfilling a responsibility is itself a benefit, but this view requires not that we define "responsibility" in terms of "benefits," as the utilitarian does, but that we define "benefits" in terms of "responsibilities." In any case, preservation of the qualities, and accordingly the values, that this nation, as a nation, has considered peculiarly its own-and these are the qualities of nature -certainly obliges us to do otherwise than follow our pleasure and our profit. Consequently, there may be reason to think that fidelity to our historic values imposes both a "benefit" and a "cost."100

What are the legal implications of this rationale for preserving the national environment? Can a citizen claim interest in the monuments of his nation's culture and history as such? Can he, more generally, assert legal membership in a cultural as well as political union? We believe that he can. Everyone allows that citizens have the right to vote, based on the Constitution; surely they have a right to participate in the culture of the nation as well. A political community does not develop independently of a cultural one, and unless people have a way of protecting their cultural as well as their political and legal institutions, eventually they may lose all of them. Now, participation in a culture must mean at least two things: individuals may contribute to it by entering the sciences or the arts, and they may become familiar with it through acquaintance with the great monuments and

106. About this problem Reinhold Niebuhr wrote:

The real question is whether a religion or a culture is capable of interpreting life in a dimension sufficiently profound to understand and anticipate the sorrows and pains which may result from a virtuous regard for our responsibilities; and to achieve a serenity within sorrow and pain which is something less but also something more than "happiness". Our difficulty as a nation is that we must now learn that prosperity is not simply coordinated to virtue, that virtue is not simply co. ordinated to historic destiny, and that happiness is no simple possibility of human experience.

R. Niebuhr, The Irony of AMerican History 54 (1952). 
achievements of their nation's past. This means, of course, that people should be able to go to the National Gallery, for example, and not have Muzak piped at them, for Muzak expresses competing and distracting properties. People have a right, moreover, at least to ensure the existence of places like Sequoia National Park and to go there if they can, without having to do the usual battle with automobiles. They can demand that the mountains be left as a symbol of the sublime, a quality which is extremely important in our cultural history, rather than be turned into an expression of the soft life, which is not. The protection of the symbols-the institutions as we have said-of our cultural tradition is a condition for the maintenance of other traditions-particularly, the legal and political tradition to which our culture gives life. Accordingly, we need to respect these symbols as well as, and on the same grounds as we respect our legal and political rights. The safeguards appropriate to environmental policy, then, are not to be found in administrative codes and procedures only; we need restraints of a more dramatic and decisive kind. These must be as strong as those which protect our most fundamental rights. If restraints on the exploitation of our environment are to be adequate, then, they must be found in the Constitution itself, either as a forthright basis for statutory action ${ }^{107}$-placing certain national paradigms in trust, ${ }^{108}$ for example-or simply as the national guarantor of those structures and relations necessary to maintain the American nation. ${ }^{109}$

To say that an environmental policy can be based on the Constitution $^{110}$ does not require, of course, a constitutional passage or article which directly concerns the environment; rather the argument would rest on the concept of nationhood, the structure created by the Constitution as a single instrument functioning in all of its parts. It is reasonable to think that cultural traditions and values constitute a condition-at least a causal one-of our political and legal freedom; and therefore insofar as the Constitution safeguards our nation as a political entity, it must safeguard our cultural integrity as well. Citizenship, then, can be seen to involve not only legal and

107. This, instead of the well-worn Commerce Clause. After all, it is the fact that the eagle soars in the mind's eye, and not that he may fly across state lines, which is important.

108. Cf. Nantucket Islands Trust Bill, S.3536 \& H.R. 15081, 93d Cong., 2d Sess. (1974).

109. See C. Black, JR., Structure and Relationship in Constitutional Law (1969).

110. Even if such a rationale were held to provide the power by which Congress creates such trusts rather than implying the limitation itself, the recognition of this view would act as a check on governmental action. For example, public, rather than private access, is implicit; standing to sue is granted citizens once such a constitutional right has been accorded judicial recognition; interference with the protection of paradigms can be enjoined. 
political but also cultural rights and responsibilities. This possibility requires a legal argument and legal argument is not offered here. But here is a suggestion for someone else to argue. The right to cherish traditional national symbols, the right to preserve in the environment the qualities we associate with our character as a people, belongs to us as Americans. The concept of nationhood implies this right; and for this reason, it is constitutionally based.

But nothing is sacred; everything changes. It is just that changes which inhibit us from sharing our common heritage should not come at the whim of the developer. Nor should they depend on the conflicting interests of outdoors-people who like to hike and swim. Far different issues are at stake. They go to our sense of ourselves as a national community. Given this fact, it is satisfying to ground the protection of the environment on our most national legal institution. The right of our citizens to their history, to the signs and symbols of their culture, and therefore to some means of protecting and using their surroundings in a way consistent with their values is as important as the right to an equally apportioned franchise ${ }^{111}$ or to participation in a party primary. ${ }^{112}$ These rights are not to be denied on economic grounds. One sees too much withdrawal, aloofness, and exile in our society not to know that. As the right of the people to membership in our culture is recognized and defined, our people will become more aware and take more advantage of their membership. If with flexible constitutional structures at hand, we nonetheless forsake our national paradigms, we will not only lose once-cherished objects; we will sacrifice the values these objects express. These are the values by which we describe our national character and purpose; they are the qualities which we associate with our nation, our environment, and with the Constitution itself. ${ }^{113}$

111. Reynolds v. Sims, 377 U.S. 533 (1964).

112. Smith v. Allwright, 321 U.S. 649 (1944).

113. One afternoon last fall $I$ was on $\mathrm{my}$ way to my class in Constitutional Law. I was going to lead a discussion of certain technicalities having to do with the application of the Fourteenth Amendment, as implemented by acts of Congress, to voting and other rights. My head was full of section numbers in the Federal Revised Statutes. I fear I was mumbling to myself, a practice I cannot recommend to those who hold reputation dear.

I happened to look up-all the way up, over the tops of the red stone buildings into the sky as the Indians of Connecticut must have seen it before the white settlers came, with the great autumnal castles of clouds as far as imagination could reach. And somehow, very suddenly, all this illimitable expansiveness and lofty freedom connected within me with the words I was tracing from the Fourteenth Amendment through the statute books-"privileges or immunities of citizens," "due process of law," "equal protection of the laws." And I was caught for a moment by the feeling of a Commonwealth in which these words had not the narrow, culture-bound, relative meaning we are able to give them in the "real" world, but were grown to the vastness that is germinal within them.

C. Black, JR., The Occisions of JUSTice: Essays Mostly on Law 29-30 (1963). 